\title{
On Cyclicality in the Current and Financial Accounts: Evidence from Nine Industrial Countries
} Jens R. Clausen and Magda Kandil 


\title{
IMF Working Paper
}

Monetary and Financial Systems Department and IMF Institute

\section{On Cyclicality in the Current and Financial Accounts: Evidence from Nine Industrial Countries}

\author{
Prepared by Jens R. Clausen and Magda Kandil ${ }^{1}$ \\ Authorized for distribution by Patricia Brenner and Samir El-Khouri
}

March 2005

\begin{abstract}
This Working Paper should not be reported as representing the views of the IMF. The views expressed in this Working Paper are those of the author(s) and do not necessarily represent those of the IMF or IMF policy. Working Papers describe research in progress by the author(s) and are published to elicit comments and to further debate.

The paper investigates cyclical fluctuations in the current and financial (formerly capital) accounts of the balance of payments and major underlying components for nine industrial countries. The empirical model uses as explanatory variables domestic output growth, price inflation, real exchange rate fluctuations, energy price inflation, global growth, and regional growth. The evidence from the estimation of the model indicates the importance of fluctuations in output growth to the cyclicality of the current and financial account balances. The necessary and sufficient condition to sustain a large current account deficit is high domestic growth, which tends to stimulate financial inflows and provides adequate resources for financing. Other factors appear to be less important to the cyclicality of the current and financial account balances and their negative correlations.
\end{abstract}

JEL Classification Numbers: F3, F4

Keywords: Current account, financial account, cointegration, reduced form equations Author(s) E-Mail Address: jclausen@imf.org,mkandil@imf.org

\footnotetext{
${ }^{1}$ Monetary and Financial Systems Department and IMF Institute, respectively. The authors would like to thank Patricia Brenner, Bianca Clausen, Samir El-Khouri, Andrew Feltenstein, and Peter Tillmann for providing valuable comments, and to Natalie Baumer, Asmahan Bedri, and Randa Elnagar for providing editorial assistance. Any remaining errors are the authors' sole responsibility.
} 


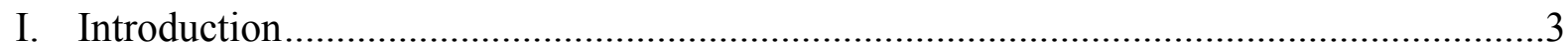

II. Analysis of Current Account Data by Country ...........................................................6

III. Modeling Cyclical Effects on the Balance of Payments..............................................6

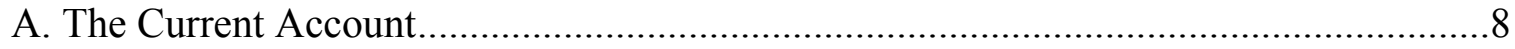
B. The Financial Account .........................................................................................
C. The Relation Between the Current and Financial Accounts .....................................10

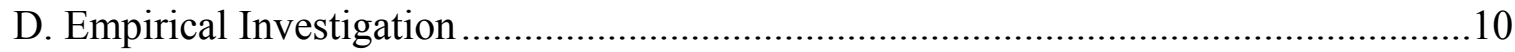

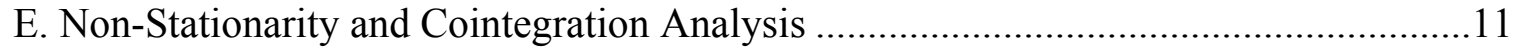

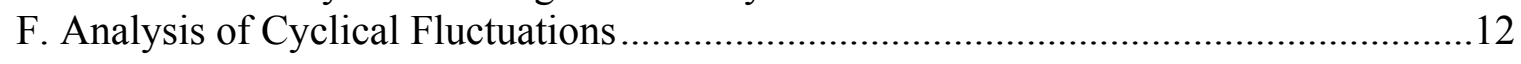

IV. Results from Reduced Form Equations ...................................................................13

A. Determinants of Fluctuations in the Current Account Balance ..................................13

B. Determinants of Fluctuations in the Financial Balance ...........................................16

V. On Correlation Between Financial and Current Accounts ............................................17

A. Cyclical Correlations Between Current and Financial Accounts................................17

B. Correlations Between Estimated Parameters for the Current and

Financial Balances ......................................................................................... 18

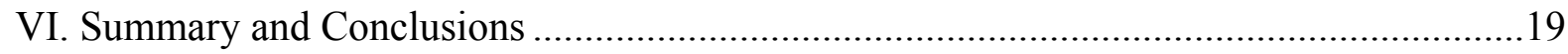

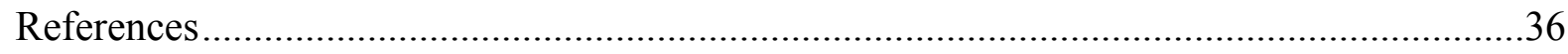

Figure 1. Average Ratio of Current Account Balance to GDP (1972-2003)..........................3

Tables

1. Current Account Balance Relative to Nominal GDP .................................................22

2. Determinants of Fluctuations in the Current and Financial Balances: Australia..............23

3. Determinants of Fluctuations in the Current and Financial Balances: Canada ................24

4. Determinants of Fluctuations in the Current and Financial Balances: Denmark...............25

5. Determinants of Fluctuations in the Current and Financial Balances: France..................26

6. Determinants of Fluctuations in the Current and Financial Balances: Germany...............27

7. Determinants of Fluctuations in the Current and Financial Balances: Italy ...................28

8. Determinants of Fluctuations in the Current and Financial Balances: New Zealand ........29

9. Determinants of Fluctuations in the Current and Financial Balances: Sweden.................30

10. Determinants of Fluctuations in the Current and Financial Balances: United Kingdom ..31

11. Correlation Between Changes in the Current and Financial Balances and

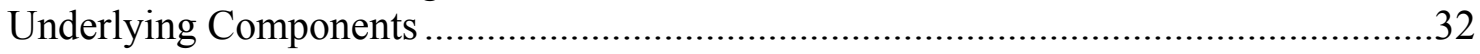

12A. Correlation Between the Responses of Financial and Current Accounts

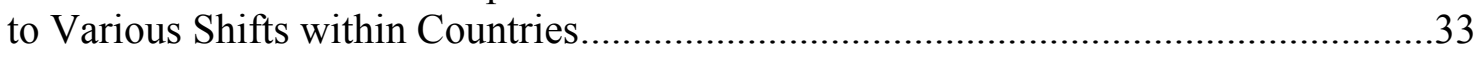

12B. Correlation Between the Responses of Financial and Current Accounts

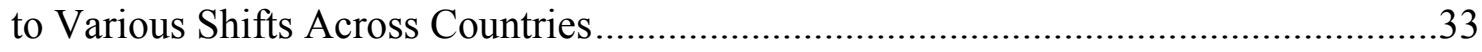

Appendixes

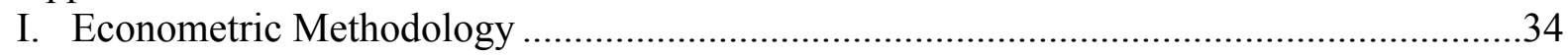

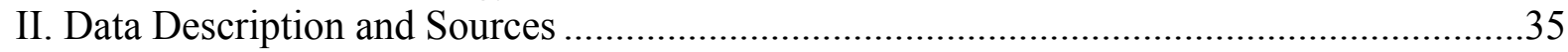




\section{INTRODUCTION}

Industrial countries have had varying experiences with fluctuations in the external current account balance. Figure 1 illustrates the average ratio of the current account balance to GDP for a sample of nine industrial countries. Variation in the current account performance, within countries over time and across countries, indicates a high degree of cyclicality. What factors determine these fluctuations over time? What are the effects of domestic business cycles, relative countries competitiveness, and economic conditions in trading partner countries on the cyclicality of the current account balance?

Figure 1. Average Ratio of Current Account Balance to GDP (1972-2003)

(In percent)

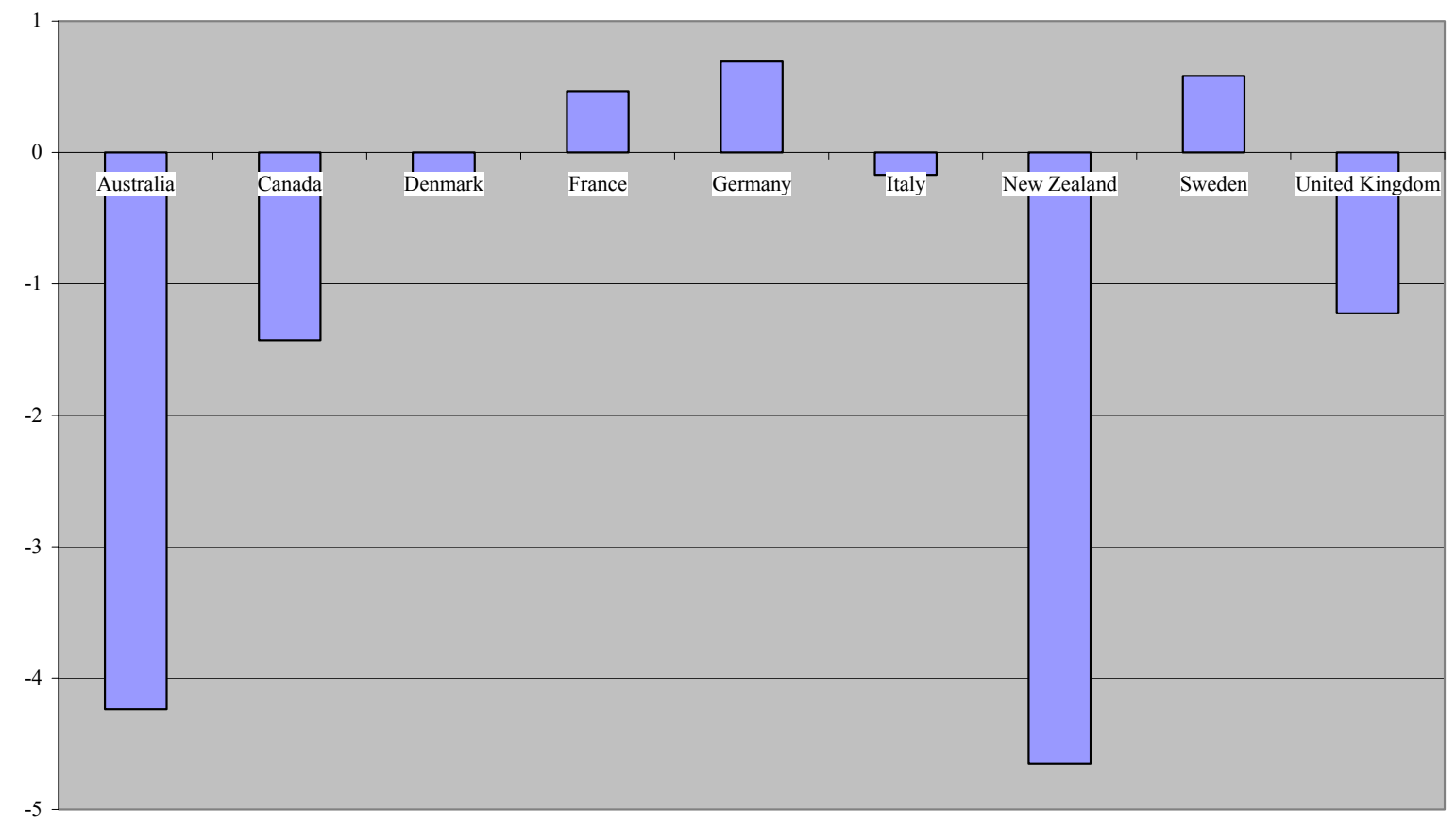

While a surplus in the current account may not elicit immediate concern (except potentially signaling the inability to attract capital flows and increase domestic investment, or a possible undervaluation of the domestic currency), a persistent current account deficit often raises concerns about its sources of financing - given limited foreign reserves. Contemporary economic theory views the analysis of current account sustainability as an intertemporal medium-term issue, turning on the ability of countries to generate sufficient current account surpluses in future years to offset present deficits. ${ }^{2}$ One strand of the recent literature has thus focused on medium-term analysis of the sort provided by Chinn and Prasad (2000), Faruqee and Debelle (2000), and Kraay and Ventura (2002). These studies have emphasized factors such as

\footnotetext{
${ }^{2}$ Questions have arisen about the sustainability of current account deficits (Milesi-Ferretti and Razin, 1996), in the sense that they can be regarded as sustainable if there is no need for significant changes in domestic macroeconomic policies.
} 
the ratio of the government budget balance and net foreign assets to GDP, relative income, the dependency ratio, and financial deepening as affecting the current account balance over the medium and longer term. A study by Bussière et al. (2004) finds that the fiscal balance, relative income, and relative investment positions determine the current account balances of the ten countries that acceded to the European Union in 2004 within an intertemporal framework. Their findings suggest that the significant current account deficits found in these countries can be traced to their investment needs. Another strand of the literature has emphasized how the ratio of the income elasticities of exports and imports varies with relative growth rates between a country and its major trading partners (see, e.g., Arora et al., 2001; and Krugman, 1989).

Faruquee and Debelle (2000) have observed that a country's position in the business cycle, as measured by the output gap and the real exchange rate, had significant short-term effects on the current account balance for a number of industrial countries during the 1971-93 period. Freund (2000) notes that, in industrial countries, a common pattern during 1980-97 was for the current account deficit to begin reversing after reaching a level of about 5 percent of GDP and to continue improving over a period of several years. The reversal typically accompanied a slowing in real GDP growth, which Freund interprets as meaning that strong income growth led to a current account deficit, while a growth slowdown or recession usually accompanied an "improvement" in the balance to a more sustainable level. In addition, most countries experienced a decline in the national saving rate before the reversal, and a drop in the investment rate afterwards (with no further change in the savings rate). This coincides with the view that current account worsening and improvement are usually counter-cyclical. Besides the growth effects, the average country experienced a cumulative real depreciation of about 20 percent beginning in the year before the maximum current account deficit. Depreciation may have been necessary for the reversal of the current account deficit.

As cyclical factors seem to have a major impact on the balance of payments, it seems worthwhile analyzing the effect of these variables in a more systematic way. The traditional approach has focused on the cyclicality of the current account deficit and the adequacy of reserves to finance imports. However, the financial account (formerly capital account ${ }^{4}$ ) has often been missing from this analysis. In addition, the growing trend to liberalize the financial account has necessitated an analysis of its cyclicality as well. It is, therefore, necessary to study the effects of domestic and external forces not only on the current account, but also on the financial account, which has been instrumental in financing or even driving a country's large current deficit. In many cases, the ability of a country to sustain large current account deficits

\footnotetext{
${ }^{3}$ We use the wording "improvement" or "worsening" not in a normative sense, but only to indicate in which direction the current or the financial account is developing.

${ }^{4}$ Our data follow the definition of the Balance of Payments Manual issued by the International Monetary Fund (IMF, 1993). Since 1993, the former capital account is redesignated as the capital and financial account. While the financial account includes portfolio and direct investment as well as reserves, the "new" capital account registers unilateral transfers such as debt forgiveness. Since the capital account in the current definition is of no major economic significance in industrial countries, we will only be looking at the financial account in the following.
} 
has turned on the willingness of foreign investors to place substantial investment funds in the country (see Arora et al., 2001; Cooper, 2001; and McKinnon 2001). ${ }^{5}$

Kandil and Greene (2002) analyze the cyclical effects in the balance of payments of the United States. This paper extends this analysis to contrast the cyclicality of the current and financial accounts in nine industrial countries. The Countries under investigation are Australia, Canada, Denmark, France, Germany, Italy, New Zealand, Sweden, and the United Kingdom. ${ }^{6}$ First, a cointegration analysis is used to verify the long-term relationship between the current and financial account balances. Cointegration tests whether the two accounts include a common stochastic trend that determines their steady-state path over time. To understand the determinants of cyclicality, we estimate a series of reduced form equations for the current and financial balances and important components of each balance.

Explanatory variables include a number of macroeconomic indicators that measure economic growth, changes in energy prices, global growth, growth in major trading partners, domestic inflation, and the change in the real effective exchange rate. Given the evidence of cyclical fluctuations in the current and financial accounts, we analyze correlations between these in the face of various shifts within countries. We also analyze correlations between cyclicalities in the current and financial balances in the face of a given shift across countries.

The results indicate the importance of output growth to cyclical fluctuations in the current and financial balances. Fluctuations induced by domestic growth are a major source of movement in the current and financial balances. During a boom, domestic absorption exceeds GNI, ${ }^{7}$ resulting in a deficit in the current account. That is, domestic investment exceeds national saving, necessitating reliance on foreign saving. Concurrently, higher growth stimulates financial inflows and improves the financial balance. The combined evidence indicates that a higher deficit in the current account in response to domestic growth goes hand in hand with its own external financing. Fluctuations in the current account balance in response to other determinants, such as a fiscal deficit, are likely to be more problematic because a situation like a twin deficit does not ensure that a country can generate sufficient funds through growth to repay the external debt. A current account deficit (and a financial account surplus) caused by high economic growth is less worrisome to the extent that external funds are used for investment, which generates a return higher than that demanded by the international investors.

The rest of the paper is organized as follows. Following an illustration of the current account data in Section II, Section III provides a theoretical background of the analysis. Section IV

\footnotetext{
${ }^{5}$ This discussion is ongoing in prominent cases such as the widening current account deficit in the United States.

${ }^{6}$ For related empirical work on sources of economic fluctuations, see Blanchard and Quah (1989), Ahmed and Park (1994), Clarida and Gali (1994), Baxter (1995), Eichenbaum and Evans (1995), Chari et al. (1998, 2001), Lane (1999), Gali (1999), Prasad (1999), and Stock and Watson (2003).

${ }^{7}$ Gross national income (GNI) equals gross domestic product (GDP) plus net foreign income for labor and investment and current transfers.
} 
reports the results of non-stationarity and cointegration analysis of the current and financial accounts. Section V reports the results of the reduced form equations that evaluate determinants of short-term cyclicality in the current and financial accounts. Section VI summarizes the main findings of the paper.

\section{Analysis of Current Account Data by Country}

Table 1 at the end of the paper illustrates data for the current account balances in nine industrial countries, from 1979 to 2003. Countries with notable deficits in the current account balance for most of the time span are Australia, Canada, New Zealand, and the United Kingdom. ${ }^{8}$ The absolute size of the current account balance has varied significantly over the business cycle and at times the balance has shifted in sign.

In Australia, the current account has been in deficit, ranging in absolute terms from a low of 1.9 percent of GDP in 1979 to a high of 6.1 percent in 1989. Canada ran a large deficit in the current account balance throughout the 1980s and most of the 1990s. More recently, the current account has been registering a surplus. In Denmark, the current account registered a deficit throughout the 1980s and a surplus since the early 1990 s.

In France, the deficit in the current account was modest throughout the 1980s and turned into a surplus in the early 1990s. In contrast, Germany experienced huge surpluses in the current account in the latter half of the 1980s and deficits in the 1990s. In 2001 to 2003, the current account registered a surplus again. In Italy, the current account was in deficit with the exception of the latter half of the 1990s. The current account remained in deficit in New Zealand, ranging in absolute terms from a low of 0.95 percent of GDP in 1988 to a high of 8.90 percent of GDP in 1984.

Sweden experienced a deficit in the current account during most of the 1980s, which turned into a surplus in the mid 1990s. In the United Kingdom, the current account was in deficit for the most part, ranging from a low of 0.16 percent of GDP in 1985 to a high of 5.12 percent of GDP in 1989.

\section{Modeling Cyclical Effects on the Balance of Payments}

The focus of the investigation is on the analysis of cyclicality in the current account. The accounting relationship in the balance of payments indicates that a deficit in the current account may either be associated with an increase in the financial balance (when excluding reserves) or a reduction in foreign reserves.

The theoretical literature suggests that the main components of the balance of payments, in particular, the current account balance, are sensitive to cyclical economic factors. Developments

\footnotetext{
${ }^{8}$ For an analysis of the United States current account deficit, which ranged from 0.8 percent in relation to GDP in 1992 to 4.5 percent in 2000, see Kandil and Greene (2002).
} 
in the financial account, with the exception of foreign direct investment, are likely to be more random in nature and, therefore, can be reversed quickly. Short-term capital flows are often attracted to higher return, which could be very cyclical in nature and, therefore, not necessarily sustainable based on underlying macroeconomic fundamentals. In contrast, the long-term nature of foreign direct investment, coupled with the difficulty to reverse these flows, necessitates a careful evaluation of underlying macroeconomic fundamentals in host countries.

We study developments in both the current and financial accounts and provide an intuitive explanation for emerging patterns. We aim to study determinants of cyclicality in relation to domestic macroeconomic conditions, relative competitiveness, regional conditions, and global conditions. We analyze fluctuations in the current account balance and two major underlying components: exports and imports. The current account includes the balances of goods, services, income, and current transfers accounts. Fluctuations in the income and current transfers account may moderate the effects of exports and imports on the current account.

Similarly, we analyze fluctuations in the financial balance and its two underlying components: inflows and outflows. Inflows comprise direct investment in the country, portfolio investment liabilities, financial derivative liabilities (if available), and other investment liabilities. Outflows are defined as the sum of direct investment abroad, portfolio investment assets, financial derivative assets (if available), and other investment assets.

Determinants of domestic cyclical fluctuations in the current and financial balances include output growth and price inflation. Both variables indicate the state of the business cycle. During a boom, output growth and price inflation increase. ${ }^{9}$ We disaggregate output growth into anticipated and unanticipated components. Anticipated growth measures steady-state

growth over time. The effects of anticipated growth on components of the balance of payments are likely to be of long-lasting nature. In contrast, unanticipated growth reflects random shocks that vary with business cycles.

To capture fluctuations in relative prices and, in turn, competitiveness, the empirical model includes the real effective exchange rate. The energy price may determine both the current and financial accounts of industrial countries through trade and financial investment. To capture the

\footnotetext{
${ }^{9}$ Kraay and Ventura (2002) document the impact of income fluctuations on the current account. Countries smooth their consumption by raising savings when income is high and vice versa. In the short-run, countries invest most of their savings in foreign assets. Fluctuations in savings lead to fluctuations in the current account that are equal to savings times the share of foreign assets in the country portfolio. The ability to purchase and sell foreign assets allows countries not only to smooth their consumption, but also their investment. Foreign assets and the current account absorb part of the volatility of these other macroeconomic aggregates.

${ }^{10}$ Unanticipated shocks are random components of an observed variable that have, by construction, a zero mean. Thus, they should have only temporary effects on a variable that cancel out over time. Forecastable growth, by comparison, is the domain of real growth factors that are more likely to have longer lasting effects on a variable.
} 
state of global and regional conditions, the explanatory variables include real growth in the United States and in major trading partners.

The effects of the above variables on the current and financial accounts are explained as follows:

\section{A. The Current Account}

Both economic theory and the work of other researchers suggest that the external current account balance should be sensitive to domestic economic conditions. ${ }^{11}$

As noted earlier, Freund (2000) found that the current account balances of most industrial countries have responded to changes in real GDP growth, with deficits typically widening during the expansionary phase of a business cycle and contracting or becoming surpluses as real GDP growth declines. This is because investment and imports are likely to increase during an economic boom. ${ }^{12}$ Thus, we would expect real growth to have a negative impact on the current account balance, raising imports of goods and services. We will analyze whether this relationship is supported by our data.

Domestic inflation usually increases with domestic growth. There are two channels through which domestic inflation affects export growth: a scale factor and a relative price channel. The former channel suggests an increase in export growth with improved economic conditions and, hence, domestic price inflation. Concurrently, due to the latter effect higher price inflation decreases export competitiveness. The net effect on exports will depend on the relative strength of the scale and competitiveness channels.

Higher inflation increases demand for foreign products relative to domestic products, resulting in an increase in imports. The effects of price inflation on exports and imports will determine changes in the current account balance in the face of higher price inflation. ${ }^{13}$

\footnotetext{
11 Theoretical small open economy models are rare in New Open Economy Macroeconomics. Obstfeld and Rogoff (1995) provide the starting point for the analysis. In their model, however, the current account is always in equilibrium, even in the short-run. Lane (1999) presents a small open economy model that allows for short-run current account imbalances and offers limited empirical support for his model.

12 The cyclicality of domestic investment relative to national savings is crucial to determine the cyclicality of the current account balance. In countries where domestic savings are low, boom periods do not result in a significant increase in savings. Other components of national savings, namely net foreign income and current transfers, are likely to be less dependent on domestic cyclical conditions. Hence, the cyclicality of domestic investment is likely to be more dominant in determining cyclical fluctuations in the current account balance than net foreign income and current transfers.

${ }^{13}$ For details, see Houthakker and Magee (1969).
} 
The effect of a higher energy price on the current account is likely to vary with a number of factors. For oil importing countries, imports increase in the face of a higher energy price. Nonetheless, exports may increase in response to a higher demand from oil-producing countries.

An increase in the real exchange rate, a real appreciation, is likely to decrease competitiveness, increasing imports and decreasing exports. The resulting deterioration in the trade balance is likely to worsen the current account balance. ${ }^{14}$ The effect of global growth or growth in major trading partners on the current account balance is likely to vary depending on its relative effects on exports and imports. If a country is more competitive relative to major trading partners, external growth should have a larger positive impact on its exports relative to imports, improving the country's current account balance. ${ }^{15}$

\section{B. The Financial Account}

The impact of cyclical factors on the financial account of the balance of payments may be harder to predict. Given the openness of the financial account in industrial countries, financial flows in and out of these countries are driven by competitiveness. In this sense, a current account deficit accompanying a financial account surplus could be identified as signaling relatively favorable economic conditions in a country. This would contrast the perspective of a current account surplus signaling competitiveness.

Higher domestic growth in one country, compared to its competitors, may increase foreign direct investment and financial inflows. The financial balance is likely to improve in response to better economic conditions in the domestic economy. Good investment opportunities attract financial inflows, which then provide the necessary savings to fund investment and, thereby, contribute to higher growth. Therefore, an improvement in the financial account balance is associated with higher GDP growth and/or price inflation. Hence, both domestic and foreign growth matter to the relative financial position of an industrial country compared to other financial competitors.

\footnotetext{
${ }^{14}$ It is possible, however, that currency depreciation may worsen the trade balance initially. This is consistent with a J-curve effect. In cases where the economy is highly dependent on imports, depreciation increases the value of imports, worsening the trade balance.

${ }^{15}$ Bergin and Sheffrin (2000) develop a testable inter-temporal model of the current account that allows for variable interest rates and exchange rates. They view these additional variables as channels through which external shocks may influence the domestic current account. In their words (p. 555), "the current account of a small open economy is likely to be affected not only by shocks to domestic output or government expenditure, but also by external shocks to the economies of large neighbors. Such external shocks should be expected to affect the domestic economy via changes in the world interest rate and the country's real exchange rate, both of which set the terms by which the small open economy can trade inter-temporally with the rest of the world." In our model, we capture the external channels through the real effective exchange rate, global growth, and growth of major trading partners.
} 
An increase in the real effective exchange rate may improve or worsen the financial balance. ${ }^{16}$ An appreciation of the exchange rate may signal the strength of the domestic economy, which further increases net financial inflows. Alternatively, an appreciation decreases the relative value of financial inflows in domestic currency while increasing the relative value of financial outflows in foreign currency. This scenario is consistent with a reduction in net financial inflows. Higher energy prices may be consistent with an increase in financial inflows to industrial countries from oil-producing countries, resulting in an improved financial balance.

There are two scenarios to explain the effects of improved global and regional conditions on the financial balance of industrial countries. In one scenario, higher external growth may attract capital outflows and worsen the financial balance. In another scenario, foreign growth may generate a larger influx of financial flows, improving the financial balance. The net result will depend on the relative strengths of both channels.

\section{The Relation between the Current and Financial Accounts}

To what extent is a widening current account deficit accompanied by an increase in financial inflows and an improvement in the financial balance? If one abstracts from the capital account (because it does not play a significant role) as well as omissions and errors, there has to be an inverse relationship between the current account and the financial account (with reserves being a part of the financial account). One implication is that net inflows in the financial account balance (including changes in official reserves) essentially finance current account deficits. It is expected, therefore, that fluctuations in the current and financial accounts will carry opposite signs in the face of the above determinants. ${ }^{17}$

\section{Empirical Investigation}

The countries under investigation are Australia, Canada, Denmark, France, Germany, Italy, New Zealand, Sweden, and the United Kingdom. The sample period extends from 1975 to 2002 for all countries, except for Australia and New Zealand, where the sample period extends from 1978 to 2002 due to data limitation. ${ }^{18}$

The empirical investigation will proceed in two steps. First, we test for non-stationarity and cointegration in the data. Second, we estimate reduced form equations for the current account

\footnotetext{
${ }^{16}$ At the same time, one could argue that net financial inflows cause a real appreciation.

${ }^{17}$ Sarisoy-Guerin (2003) examines the relationship between current accounts and financial accounts in a set of industrial and developing countries. Specifically, the focus is on the link between net capital inflows and the current account. Country experiences vary. The evidence implies that inflows do not cause current account imbalances in the industrial countries, nor does the inflow volatility affect current account volatility. In contrast, there is a relationship between volatility of inflows and current accounts in developing countries. During an economic downturn, sudden reversals in inflows can induce a liquidity crisis. In favorable times, there may be overlending, exceeding the optimal amount required by the consumption-smoothing hypothesis.

${ }^{18}$ For description of series and data sources see Appendix II.
} 
balance, exports of goods and services, imports of goods and services, the financial account balance, inflows in the financial account balance, and outflows in the financial account balance.

\section{E. Non-Stationarity and Cointegration Analysis}

The following sets of variables are used: a set of domestic explanatory variables that consists of real GDP, the GDP deflator, energy prices, and the real effective exchange rate (REER). The set of "dependent" variables consists of the current account balance, exports of goods and services, imports of goods and services, the financial account balance, and inflows and outflows in the financial account.

\section{Non-stationarity test results}

All variables are tested for non-stationarity. ${ }^{19}$ For Australia, all variables, except for the REER, the current account balance, and the financial account balance are non-stationary. For Canada, all variables, except for financial inflows, are non-stationary. For Denmark, all variables, except for financial outflows, are non-stationary. For France, all variables are non-stationary, except for real GDP. For Germany, all variables, except for the current account balance, are nonstationary. For Italy, all variables are non-stationary, except for real GDP, the current account balance, the financial account balance, and inflows. For New Zealand, all variables, except for the financial account balance and inflows are non-stationary. For Sweden, all variables, except for the REER, financial inflows and outflows, are non-stationary. For the United Kingdom, all variables are non-stationary.

\section{Cointegration relations among current and financial accounts}

Having assessed non-stationarity, this section investigates the evidence of cointegration among the non-stationary components of the balance of payments. The accounting identity indicates a close association between the current and financial balances as movements in the subcomponents offset each other. Cointegration tests evaluate the close association between stochastic trends underlying movements in the subcomponents over time. Conflicting disturbances in each account may divert their stochastic trends in the long-run, notwithstanding the accounting identity. The evidence of cointegration is based on the results of the Johansen test (Johansen 1988, 1992) and are available upon request.

The evidence indicates that the financial and current account balances exhibit common stochastic trends in Canada, Denmark, France, Sweden, and the United Kingdom. In Australia, while the financial and current account balances are not cointegrated, their underlying components exhibit a common stochastic trend. In Germany, the financial balance and its underlying components exhibit a common stochastic trend with the components of the current account balance. In Italy, only outflows exhibit a common stochastic trend with exports and

\footnotetext{
${ }^{19}$ The non-stationarity test follows the approach suggested by Dickey (1976). Detailed results are omitted due to space constraints and are available upon request.
} 
imports. In New Zealand, only outflows exhibit a common stochastic trend with the current account balance and its underlying components.

Overall, the evidence indicates a strong long-run relationship between the current and financial account balances or their underlying components.

\section{Cointegration among dependent and explanatory variables}

Before undertaking the analysis of determinants of cyclical fluctuations in the current and financial balances, it is important to verify the nature of the long-run relationship between the dependent and explanatory variables that are proven to be non-stationary.

We carry out a residual based cointegration test following Engle and Granger (1987). ${ }^{20}$ Given evidence of cointegration, an error-correction term (the lagged value of the residual in the cointegration regression) is included in the empirical models explaining the cyclicality of the dependent variables. ${ }^{21}$ The results are available upon request.

\section{F. Analysis of Cyclical Fluctuations}

Let $X$ be the dependent variable, which is measured as the current account balance, the log of exports, log of imports, the financial account balance, log of inflows, or log of outflows. ${ }^{22}$ The empirical model is specified in first-difference form as follows: ${ }^{23}$

$$
\begin{gathered}
D X_{t}=a_{0}+b_{1} E_{t-1} D y_{t}+b_{2}\left(D y_{t}-E_{t-1} D y_{t}\right) \\
+b_{3} D p_{t}+b_{4} \text { Dreer }_{t}+b_{5} \text { Denergy }_{t}+b_{6} D y_{t}^{U S}+b_{7} D y_{t}^{M T}+b_{8} E C_{t-1}+v_{t}^{x} .
\end{gathered}
$$

The change in the current account, financial account, or underlying components is related to domestic and foreign fluctuations. Domestic variables include output growth, $D y_{t}$, price

\footnotetext{
${ }^{20}$ To do that, the respective dependent variable is regressed on the non-stationary domestic variables (with all variables being in levels). The residual term resulting from this OLS regression is then tested for stationarity. The lag length for the residual-based cointegration tests is chosen according to standard lag length criteria. Neither a constant nor a trend are assumed for the augmented auto-regressions (augmented Engle/Granger tests). As the asymptotic distributions of the residual-based test statistics are not the same as for ordinary series in ADF test statistics, different critical values have to be used and are taken from Davidson/MacKinnon (1993, Table 20.2, p. 722). If the respective residual term turns out to be stationary, there exists at least one cointegrating vector that combines the stochastic common trends in the dependent and explanatory variables.

${ }^{21}$ If there is no evidence of cointegration, the residual term proves to be non-stationary, we do not introduce an error term into the reduced-form model specification.

${ }^{22}$ Because the current and financial account balances could take negative values, they were estimated as changes in levels. In addition, the inflow and outflow series for Denmark, New Zealand, and Sweden switch signs at some data points. Accordingly, these series cannot be transformed into logs.

${ }^{23}$ Given evidence of non-stationary dependent variables, the first-difference specification renders the transformed series stationary.
} 
inflation, $D p_{t}$, the rate of appreciation in the real effective exchange rate, Dreer $_{t}$, and energy price inflation, Denergy ${ }_{t}$. To separate long-lasting effects from transitory fluctuations, we separate domestic output growth into anticipated and unanticipated components, where $E_{t-1} D y_{t}$ denotes rational expectation forecasts given information available to agents at time $t-1$.

To capture global economic conditions, we include real output growth in the United States, $D y_{t}^{U S}$, in all equations for various countries. ${ }^{24}$ In addition, we include a proxy for growth in major trading partners. This proxy is measured by real output growth in the euro area for European countries, real growth in Australia for New Zealand, and real growth in Japan for Australia. Given evidence of cointegration between the non-stationary dependent variable and non-stationary domestic explanatory variables, we include an error-correction term, $E C_{t-1}$ in the model specification. ${ }^{25}$ The error-correction term is the lagged value of the residual in the cointegration regression.

\section{RESULTS FROM REDUCED FORM EQUATIONS}

We estimated reduced-form equations that illustrate cyclical fluctuations in the current account, exports, imports, the financial account, inflows and outflows jointly along with the equation that generates agents' forecasts of real growth using 3SLS. Results are summarized in Tables 2 through 10 for each of the countries under investigation. We provide a summary of the evidence and implications.

\section{A. Determinants of Fluctuations in the Current Account Balance}

Across countries, anticipated real output growth decreases the current account balance significantly in one country (Germany). Unanticipated real output growth decreases the current account balance significantly in three countries (Denmark, France, and New Zealand) and increases it significantly in one country (Italy). The bulk of the evidence indicates that the current account balance moves counter-cyclically with economic growth, and the relationship is mostly transitory.

There is no evidence of a significant effect of price inflation or the real exchange rate on the current account balance in any country. Relative competitiveness, via the exchange rate or domestic inflation, does not appear to be an important factor that determines the state of the current account in industrial countries.

\footnotetext{
${ }^{24}$ Hoffmann (2003) employs inter-temporal models to identify global and country-specific shocks in a bi-variate VAR of output and the current account. Shocks orthogonal to the current account can be associated with growth in United States real GDP. Hence, shocks to the current account are country-specific. Global shocks do not affect the current account.

${ }^{25}$ To account for the endogeneity of right-hand side variables, instrumental variables are used (for details, see Appendix I).
} 
An increase in the energy price improves the current account balance significantly in two countries (Australia and Canada). Growth in the United States improves the current account balance significantly in one country (France). The current account balance worsens significantly in the face of improved growth in the euro area in one country (Italy).

Overall, the evidence indicates the unsystematic nature of fluctuations in the current account balance. Among the variables under consideration, fluctuations in real output growth appear relatively more important to the cyclicality of the current account balance. ${ }^{26}$

\section{Determinants of fluctuations in export growth}

Anticipated growth increases exports significantly in two countries (New Zealand and the United Kingdom). Unanticipated growth increases exports significantly in two countries (New Zealand and Sweden). In general, exports do not vary closely with domestic growth.

In contrast, price inflation increases export growth significantly in seven countries (Canada, Denmark, France, Italy, New Zealand, Sweden and the United Kingdom). Export growth does not appear to be adversely affected by domestic price inflation in many industrial countries. ${ }^{27}$ This indicates that the scale factor is stronger than the relative price channel.

An increase in the energy price is consistent with an increase in export growth in four countries (Denmark, New Zealand, Sweden, and the United Kingdom) This result indicates that oilproducing countries constitute a major share of the export market for many of the countries under investigation.

An increase in the real exchange rate (currency appreciation) decreases export growth significantly in six countries (Australia, Canada, Denmark, France, New Zealand, Sweden, and the United Kingdom). Consistent with theory's prediction, a real currency appreciation decreases export competitiveness and, therefore, decreases export growth. ${ }^{28}$

\footnotetext{
${ }^{26}$ For related empirical work, see Billmeier (2002) who considers current account behavior conditional on a nominal shock for G-7 countries. It is found that the reaction of the current account is profoundly different across countries, ranging from a J-curve effect (United States, Japan, and Italy) to purely cyclical movements (United Kingdom and Canada). Furthermore, the importance of nominal shocks in explaining the current account varies across countries, but is never the main explanatory component. He concludes that there is a need for microfounded current account models that stress country-specific particularities.

${ }^{27}$ This may be an indication of capacity constraints that lead to an increase in price inflation in the face of excess demand.

${ }^{28}$ Muler-Platenberg (2003) reports that Japan's long-lasting current account surplus as well as Germany's temporary surplus during the 1980s are the two largest current account surpluses the world has witnessed. Remarkably, net exports were rising in both countries despite the large overall appreciation of the Japanese yen and the considerable strength of the deutsche mark. He demonstrates, however, that both countries' current accounts, while overall rising, experienced several setbacks and subsequent recoveries, with clear turning points. It further demonstrates that current account reversals were triggered by the real exchange rate appreciating, or depreciating,
} 
Growth in the United States stimulates export growth in one country (Sweden). Growth in major trading partners does not affect export growth significantly in any country.

The combined evidence indicates that export growth in many industrial countries is highly dependent on domestic conditions and relative competitiveness; it is less dependent on global or regional conditions.

\section{Determinants of fluctuations in import growth}

An increase in anticipated growth increases imports significantly in two countries (Australia and the United Kingdom). An increase in unanticipated growth increases imports significantly in four countries (Australia, Denmark, New Zealand, and Sweden). While real growth stimulates demand for imports, the relationship is mostly cyclical.

Domestic price inflation increases imports significantly in four countries (Canada, France, Italy and New Zealand). An increase in price inflation increases the cost of non-tradables and, therefore, the demand for imports.

An increase in the energy price increases imports significantly in five countries (France, Germany, Italy, New Zealand, and the United Kingdom), indicating high dependency of industrial countries on energy imports.

There is no evidence of an increase in imports in the face of currency appreciation. In support of a J-curve effect, the negative significant signs indicate that currency depreciation increases imports in six countries (Canada, Denmark, France, Italy, New Zealand, and Sweden). That is, the price effect dominates the quantity effect on imports following a change in the exchange rate. $^{29}$

United States growth increases imports significantly in one country (Canada). Geographical proximity, among other things, has enhanced trade relations between the two neighboring countries.

Overall, imports are highly dependent on domestic growth and price inflation. Under a flexible exchange rate regime, fluctuations in the currency value are not effective to induce necessary changes in imports in the short-run. Global and regional conditions have minimal effects on import growth in industrial countries.

\footnotetext{
too strongly.

${ }^{29}$ As Leonard and Stockman (2001) report "Most economists assert that a J-curve phenomenon characterizes the data: that currency depreciation leads initially to current account deficits and subsequently to current account surpluses." Actual empirical studies on this issue, however, have shown a very mixed set of results. Leonard and Stockman's evidence is weak regarding a J-curve in the data.
} 


\section{B. Determinants of Fluctuations in the Financial Balance}

Except for Germany, anticipated growth does not determine the financial balance significantly in any country. The financial balance improves significantly in the face of unanticipated growth in two countries (Denmark and France). There is no evidence of significant effect of domestic inflation on the financial balance in any country.

The evidence of significant variation in the financial balance with the energy price is limited to one country (Australia) where the coefficient is negative and statistically significant. There is no evidence of significant variation in the financial balance with the real exchange rate in any country, except Sweden. Similarly, the financial balance does not vary significantly with United States growth in any country. Hence, global conditions do not appear to be closely tied to the financial balance of industrial countries. Growth in the euro area improves the financial balance significantly in one country (Sweden).

Overall, the randomness of the financial balance does not appear to be well explained by cyclical fluctuations in domestic and external variables included in the model.

\section{Determinants of financial inflows}

Anticipated growth does not determine financial inflows significantly in any country. In contrast, unanticipated growth increases financial inflows significantly in one country (Australia). Consistent with improved economic conditions, price inflation significantly increases financial inflows in one country (Italy). There is no evidence of a significant increase in financial inflows in the face of a higher energy price in any country.

Financial inflows decrease significantly in the face of currency appreciation in one country (New Zealand). Appreciation decreases the value of foreign assets and return on foreign investment. UNITED STATES growth is consistent with a significant reduction in financial inflows in one country (Australia) and with a significant increase in another country (Italy). Growth in major trading partners does not determine financial inflows significantly in any country.

Overall, the evidence indicates a high level of randomness surrounding financial inflows into industrial countries. This randomness is not fully explained by cyclical fluctuations in domestic and foreign variables in the model. ${ }^{30}$

\section{Determinants of financial outflows}

As agents develop better expectations of economic conditions, anticipated growth decreases financial outflows significantly in one country (Canada). Similarly, a positive shock to output

\footnotetext{
${ }^{30}$ This may be explained by the fact that most industrial countries have liberalized financial accounts. Domestic markets are open to foreign capital inflows and domestic agents are also free to invest abroad.
} 
growth decreases financial outflows significantly in one country (Germany). Price inflation is consistent with a significant increase in financial outflow in one country (Italy) as higher inflation reduces the real return on financial investment.

An increase in the energy price does not determine financial outflows significantly in any country. Similarly, financial outflow does not vary significantly with the currency value relative to other major trading partners. An increase in growth in the United States is consistent with an increase in financial outflow in two countries (Canada, Italy). In these cases, the prospects of growth in the United States attract financial investors in these countries. In contrast, growth in major trading partners does not determine financial outflows significantly in any country.

Overall, the evidence indicates a high degree of randomness associated with financial outflows. Cyclical fluctuations in explanatory variables do not explain much of this randomness.

\section{On CORRELATion between FinanCial AND CurRent ACCOUnTS}

The above evidence highlights the unique nature of cyclical fluctuations in the current and financial accounts. It is difficult to generalize major determinants across countries. Nonetheless, the accounting relationship suggests a negative correlation between the current and financial accounts. We investigate to what extent this relationship holds for the changes of both accounts and their underlying components. We proceed in two steps. First, we demonstrate correlations between fluctuations in the current and financial balances and their underlying components. Second, we demonstrate factors underlying these correlations. To that end, we study correlations between the responses of the current and financial accounts to domestic and foreign variables within and across countries.

\section{A. Cyclical Correlations Between Current and Financial Accounts}

Table 11 presents time-series correlations across countries between the change in financial and current accounts as well as underlying components, the growth of exports, imports, financial inflows, and outflows.

In column (1), the correlation coefficient is negative and significant between the change in the current and financial accounts for all countries, ranging from a small (speaking in absolute terms) coefficient of -0.39 in Denmark to a large coefficient of -0.96 in Australia. Consistently, correlation coefficients between the change in the current account and financial inflows are negative for most countries (5/9), although statistically insignificant. Financial inflows increase as the current account deteriorates. ${ }^{31}$ The correlation coefficient between outflows and the current account balance is positive in most countries (7/9), although significant in one country (Australia). In this case, financial outflows increase as the current account balance improves.

\footnotetext{
${ }^{31}$ A deficit in the current account indicates that national savings fall below domestic investment. This gap is financed (or caused) by attracting capital inflows or borrowing.
} 
The correlation between the current account balance and exports is positive and significant in two countries (Australia and Sweden). Higher export growth improves the current account balance. The correlation coefficient is negative between imports and the current account balance, which is statistically significant for three countries (France, Germany, and New Zealand). An increase in imports deteriorates the current account balance. ${ }^{32}$

Financial inflows correlate positively with the financial balance with coefficients that are positive and statistically significant in two countries (Canada and New Zealand). An increase in outflows correlates negatively and significantly with the financial balance in one country (Australia), indicating deterioration in the financial balance. ${ }^{33}$

The financial balance correlates negatively and significantly with export growth in one country (Australia). As exports increase, the financial balance deteriorates. In contrast, an increase in imports correlates with an increase in the financial balance that is positive and significant in two countries (France and Germany). This supports the negative correlation between changes in the current account and financial balances. Higher imports deteriorate the current account balance and correlate with an improved financial balance.

Overall, correlation coefficients establish the negative relationship between fluctuations in the current and financial balances. Movements in underlying components support these correlations in a few cases.

\section{B. Correlations between Estimated Parameters for the Current and Financial Balances}

Reduced form estimates measure the responses of the current and financial balances to specific domestic and foreign shocks. We seek to identify sources of the negative correlations between the current and financial balances. To that end, we present two sets of correlations. The first set measures correlations between the responses of the financial and current balances to various shifts within countries. The second set illustrates correlations between the responses of the current and financial accounts to a given shift across countries.

\section{Correlations between the responses to various shifts within countries}

We gather correlations between the responses of the current and financial balances to various shifts within countries. These correlations are reported in Table 12.A.

\footnotetext{
${ }^{32}$ The current account includes the balances of goods, services, income and current transfers accounts. Exports and imports are of goods and services. Fluctuations in the income and current transfers account may moderate the effects of exports and imports on the current account.

${ }^{33}$ Inflows and outflows are based on transactions affecting direct investment, portfolio investment, financial derivatives, and other investment. The financial balance comprises other transactions that include the financial position of the government account. Fluctuations in this balance may moderate the effects of private inflows and outflows on the financial balance.
} 
In all countries, correlation coefficients are negative, ranging from a low of -0.46 in the United Kingdom to a high of -0.99 in Australia and Germany. Combining all countries, the correlation coefficient equals -0.85 in the face of various shifts. The above correlations indicate that the current and financial accounts tend to move in opposite directions in the face of a composite of shifts impinging on a given economy.

\section{Correlations between the responses to a given shift across countries}

In an attempt to identify determinants of the negative correlation between the current and financial balances, the next set of correlation coefficients, reported in Table 12.B, measures correlations between the current and financial accounts in the face of specific shifts across countries.

The negative and significant coefficients, -0.97 and -0.88 , indicate that domestic growth is a major determinant of the negative correlation between the current and financial accounts. An increase (decrease) in growth, both anticipated and unanticipated, correlates with an increase (decrease) in the current account deficit, that appears to be correlated with an improved (deteriorated) financial balance.

The correlation coefficient, -0.87 , indicates that growth for major trading partners generates a large negative correlation between fluctuations in the current and financial accounts. Higher growth for major trading partners may be consistent with an increase in exports, which would improve the current account balance. Consistently, capital outflow to neighboring countries will increase as a result.

Other correlation coefficients are small, discounting their relevance to the negative relationship between cyclical fluctuations in current and financial balances.

\section{SumMARY AND CONCLUSIONS}

The goal of this paper is to assess the cyclical sensitivity of key components of the balance of payments in nine industrial countries. The empirical model relates these components to real GDP growth, the inflation rate, the real effective exchange rate, the change in energy price, real growth in the United States (a proxy for global growth), and real growth in major trading partners.

The complexity of the channels determining the interaction between domestic and foreign variables and components of the current and financial balances demands a thorough empirical investigation. Our investigation proceeds in steps. First, we test for cointegration between the current and financial balances and major underlying components. Cointegration implies the presence of a long-term relationship between the current and financial balances. Second, we test whether key domestic macroeconomic variables are cointegrated with the current and financial account balances to see whether significant long-term relationships exist between these balances and the different explanatory variables. Third, we estimate a variety of short-term reduced-form equations for the current account balance, the balance of the financial account, and their main 
components. The estimated equations relate each of these items to domestic and foreign determinants of fluctuations in the current and financial balances. To separate long-lasting effects from random shocks, domestic growth is separated into an expected and an unexpected component.

Cointegration tests confirm long-term relationships between the current and financial balances, or their underlying components. Further, the correlation coefficient is negative between the current and financial accounts. The ability of the economy to sustain a significant current account deficit is dependent on accumulating net financial flows.

The data confirm that real growth raises imports of goods and services and, therefore, has a negative impact on the current account balance. There is no evidence that higher inflation affects the current account. That seems to be due to the offsetting effects inflation has on imports and exports. On the one hand, our results show that inflation goes hand in hand with export growth. Inflation might provide a signal of improved cyclical conditions that stimulate export growth. The notion that higher inflation reduces competitiveness and, in turn, export growth cannot be confirmed. On the other hand, our results indicate that higher domestic inflation reduces the relative prices of imports and increases the demand for imports. Inflation seems to have a positive effect on both imports and exports for the countries in our sample.

For oil importing countries, the value of imports should increase in the face of a higher energy price assuming the demand for oil is inelastic. This is confirmed by the data for the majority of countries in the sample. Nonetheless, exports also increase in the wake of higher energy prices in some countries, possibly as a response to a higher demand from oil-exporting countries.

A real currency appreciation (a rise in the real exchange rate) is likely to reduce competitiveness, increase imports, and reduce exports. Our results confirm the negative relationship between the real exchange rate and exports, but do not show the positive relationship between imports and the real exchange rate. The latter might be due to a J-curve effect. The expenditure for imports increases although the currency depreciates.

The effect of global growth or growth in major trading partners on the current account balance is likely to vary depending on relative effects on imports and exports. However, our results do not show that global or regional conditions have effects on import or export growth in the countries in our sample.

The impact of cyclical factors on the financial account of the balance of payments proved harder to predict. Our model indicates a high level of randomness surrounding the financial balance. Financial flows are affected by exogenous factors that determine relative returns and risk. Domestic and external variables included in our model have limited explanatory power of cyclical fluctuations in the financial balance and underlying components.

In general, reduced-form regressions indicate that cyclical factors have a stronger effect on short-term fluctuations in the current account compared to fluctuations in the financial account. Overall, the evidence indicates that domestic growth is the most important factor in explaining 
the current and financial balances and their negative correlations over time.$^{34}$ While fluctuations in the financial balance appear mostly random, higher domestic growth increases investors' confidence and improves the financial balance. Higher growth stimulates aggregate demand, and domestic absorption, and, in turn, stimulates demand for imports. Nonetheless, the economy is capable of generating external resources to finance higher growth without the need to fall into the trap of unsustainable debt accumulation.

The study of cyclicality in the current and financial balances has important implications for the sustainability of the current account deficit. Concerns often arise about a widening current account deficit and corrective measures needed to address this deficit. The necessary and sufficient condition to sustain a large current account deficit is high growth that stimulates financial inflows and provides adequate resources for financing. In the absence of high growth, sharp exchange rate movements (brought about by markets or induced by policy intervention) may be necessary to correct a widening current account deficit and achieve a sustainable external balance.

\footnotetext{
${ }^{34}$ Consistently, Stock and Watson (2003) report that their analysis of G-7 data indicates that, with the exception of Japan, the widespread reduction in volatility is in large part associated with a reduction in the magnitude of the common international shocks. Had the common international shocks in the 1980s and 1990s been as large as they were in the 1960s and 1970s, G-7 business cycles would have been substantially more volatile and more highly synchronized than they actually were.
} 
Table 1. Current Account Balance Relative to Nominal GDP (In percent)

\begin{tabular}{|c|c|c|c|c|c|c|c|c|c|}
\hline \multirow[b]{2}{*}{ Year } & \multirow[b]{2}{*}{ Australia } & \multirow[b]{2}{*}{ Canada } & \multirow[b]{2}{*}{ Denmark } & \multicolumn{5}{|c|}{ Shares of Current Account Balance to nominal. GDP } & \multirow[b]{2}{*}{$\begin{array}{l}\text { United } \\
\text { Kingdom }\end{array}$} \\
\hline & & & & France & Germany & Italy & $\begin{array}{c}\text { New } \\
\text { Zealand }\end{array}$ & Sweden & \\
\hline 1979 & -1.88 & -3.52 & -2.87 & 0.64 & -0.69 & 1.57 & -2.28 & -2.14 & -0.51 \\
\hline 1980 & -2.68 & -2.26 & -1.49 & -0.61 & -1.72 & -2.35 & -4.03 & -3.36 & 0.75 \\
\hline 1981 & -4.69 & -4.16 & -3.10 & -0.80 & -0.67 & -2.37 & -4.96 & -2.35 & 1.92 \\
\hline 1982 & -4.50 & 0.61 & -3.87 & -2.14 & 0.68 & -1.83 & -7.41 & -3.15 & 0.81 \\
\hline 1983 & -3.49 & -0.76 & -2.32 & -0.87 & 0.61 & 0.17 & -4.38 & -0.76 & 0.42 \\
\hline 1984 & -4.54 & -0.37 & -2.99 & -0.15 & 1.47 & -0.77 & -8.90 & 0.74 & -0.40 \\
\hline 1985 & -5.12 & -1.61 & -4.57 & -0.07 & 2.65 & -0.95 & -7.27 & -0.97 & -0.16 \\
\hline 1986 & -5.31 & -3.03 & -5.26 & 0.32 & 4.21 & 0.41 & -6.39 & 0.02 & -0.95 \\
\hline 1987 & -3.53 & -3.19 & -2.80 & -0.49 & 3.85 & -0.35 & -4.96 & -0.01 & -1.80 \\
\hline 1988 & -4.40 & -2.99 & -1.20 & -0.48 & 4.15 & -0.85 & -0.95 & -0.28 & -4.24 \\
\hline 1989 & -6.12 & -3.92 & -1.03 & -0.47 & 4.56 & -1.47 & -3.78 & -1.56 & -5.12 \\
\hline 1990 & -5.19 & -3.40 & 0.99 & -0.81 & 2.93 & -1.49 & -3.21 & -2.65 & -4.00 \\
\hline 1991 & -3.56 & -3.74 & 1.51 & -0.50 & -1.23 & -2.10 & -2.78 & -1.88 & -1.82 \\
\hline 1992 & -3.64 & -3.62 & 2.75 & 0.28 & -0.95 & -2.36 & -4.22 & -2.89 & -2.12 \\
\hline 1993 & -3.21 & -3.86 & 3.38 & 0.72 & -0.71 & 0.78 & -3.97 & -1.31 & -1.86 \\
\hline 1994 & -5.02 & -2.30 & 1.76 & 0.55 & -1.38 & 1.29 & -4.02 & 1.11 & -0.99 \\
\hline 1995 & -5.34 & -0.75 & 0.99 & 0.70 & -1.10 & 2.28 & -5.22 & 3.39 & -1.25 \\
\hline 1996 & -3.91 & 0.55 & 1.76 & 1.32 & -0.58 & 3.24 & -5.91 & 3.55 & -1.14 \\
\hline 1997 & -3.14 & -1.29 & 0.39 & 2.81 & -0.43 & 2.77 & -6.50 & 4.17 & -0.21 \\
\hline 1998 & -4.95 & -1.24 & -0.88 & 2.65 & -0.57 & 1.67 & -3.99 & 3.89 & -0.56 \\
\hline 1999 & -5.68 & 0.26 & 1.67 & 2.91 & -1.12 & 0.69 & -6.29 & 4.21 & -2.18 \\
\hline 2000 & -3.97 & 2.86 & 1.61 & 1.37 & -1.40 & -0.54 & -4.78 & 3.97 & -2.01 \\
\hline 2001 & -2.41 & 2.43 & 2.62 & 1.74 & 0.05 & -0.06 & -2.60 & 3.89 & -1.26 \\
\hline 2002 & -4.43 & 2.02 & 2.68 & 1.80 & 2.32 & -0.57 & -3.70 & 4.46 & -0.92 \\
\hline 2003 & -5.21 & 1.59 & 4.24 & 1.23 & 2.39 & -1.10 & -3.74 & 4.46 & -0.97 \\
\hline Average & -4.24 & -1.43 & -0.24 & 0.47 & 0.69 & -0.17 & -4.65 & 0.58 & -1.22 \\
\hline
\end{tabular}

Source: World Economic Outlook 
Table 2. Determinants of Fluctuations in the Current and Financial Balances: Australia

\begin{tabular}{|c|c|c|c|c|c|c|c|c|c|c|}
\hline Dep Var & Constant & $E D y$ & Dys & $D p$ & Denergy & Dreer & $D y^{u s}$ & $D y^{M T}$ & $\rho$ & $R^{2}$ \\
\hline Dcbal & $\begin{array}{l}-39.13 \\
(-0.80)\end{array}$ & $\begin{array}{r}1139.67 \\
(0.76)\end{array}$ & $\begin{array}{l}-25.82 \\
(-0.25)\end{array}$ & $\begin{array}{c}4.46 \\
(0.08)\end{array}$ & $\begin{array}{c}11.20^{* *} \\
(1.77)\end{array}$ & $\begin{array}{l}-28.81 \\
(-1.44)\end{array}$ & $\begin{array}{l}-52.15 \\
(-0.56)\end{array}$ & $\begin{array}{l}63.97 \\
(0.71)\end{array}$ & $\begin{array}{r}0.047 \\
(0.13)\end{array}$ & 0.54 \\
\hline Dexport & $\begin{array}{r}0.0025 \\
(0.04)\end{array}$ & $\begin{array}{c}0.97 \\
(0.51)\end{array}$ & $\begin{array}{r}0.83 \\
(0.78)\end{array}$ & $\begin{array}{r}0.36 \\
(0.58\end{array}$ & $\begin{array}{c}0.10 \\
(1.64)\end{array}$ & $\begin{array}{c}-0.54^{*} \\
(-2.58)\end{array}$ & $\begin{array}{c}-0.21 \\
(-0.20)\end{array}$ & $\begin{array}{c}1.51 \\
(1.49)\end{array}$ & $\begin{array}{c}-0.45 \\
(-1.59)\end{array}$ & 0.48 \\
\hline Dimport & $\begin{array}{l}-0.064 \\
(-1.11)\end{array}$ & $\begin{array}{l}3.58^{* *} \\
(1.93)\end{array}$ & $\begin{array}{l}2.76^{*} \\
(2.69)\end{array}$ & $\begin{array}{c}1.01 \\
(1.67)\end{array}$ & $\begin{array}{c}0.025 \\
(0.41)\end{array}$ & $\begin{array}{c}-0.32 \\
(-1.59)\end{array}$ & $\begin{array}{l}-0.51 \\
(-0.50)\end{array}$ & $\begin{array}{c}0.078 \\
(0.08)\end{array}$ & $\begin{array}{l}-1.40 \\
(-1.17)\end{array}$ & 0.57 \\
\hline Dfbal & $\begin{array}{c}1.85 \\
(0.83)\end{array}$ & $\begin{array}{r}-1225.24 \\
(-0.80)\end{array}$ & $\begin{array}{l}-17.62 \\
(-0.16)\end{array}$ & $\begin{array}{c}-8.78 \\
(-0.17)\end{array}$ & $\begin{array}{c}-10.71^{* *} \\
(-1.91)\end{array}$ & $\begin{array}{l}31.40 \\
(1.68)\end{array}$ & $\begin{array}{l}71.62 \\
(0.72)\end{array}$ & $\begin{array}{c}-75.93 \\
(-0.86)\end{array}$ & $\begin{array}{c}-0.40 \\
(-1.15)\end{array}$ & 0.52 \\
\hline Dinflow & $\begin{array}{c}-0.07 \\
(-0.26)\end{array}$ & $\begin{array}{l}11.14 \\
(1.25)\end{array}$ & $\begin{array}{c}9.78^{*} \\
(1.97)\end{array}$ & $\begin{array}{c}3.51 \\
(1.21)\end{array}$ & $\begin{array}{c}-0.028 \\
(-1.10)\end{array}$ & $\begin{array}{c}-0.18 \\
(-0.19)\end{array}$ & $\begin{array}{l}-9.01 * * \\
(-1.80)\end{array}$ & $\begin{array}{c}-2.08 \\
(-0.44)\end{array}$ & $\begin{array}{c}-0.33 \\
(-1.08)\end{array}$ & 0.37 \\
\hline Doutflow & $\begin{array}{c}0.34 \\
(0.38)\end{array}$ & $\begin{array}{l}-10.80 \\
(-0.37)\end{array}$ & $\begin{array}{r}-8.04 \\
(-0.50)\end{array}$ & $\begin{array}{c}4.34 \\
(0.46)\end{array}$ & $\begin{array}{c}0.80 \\
(0.84)\end{array}$ & $\begin{array}{l}-2.57 \\
(-0.81)\end{array}$ & $\begin{array}{c}-0.43 \\
(-0.03)\end{array}$ & $\begin{array}{c}0.25 \\
(0.02)\end{array}$ & $\begin{array}{c}-0.32 \\
(-1.08)\end{array}$ & 0.13 \\
\hline
\end{tabular}

Notes:

- The dependent variable is in the following order: the first difference of the change in the current account balance, the first difference of the log value of exports, and imports, the first difference of the change in the financial balance, and the first difference of the log value of inflows and outflows.

- EDy is the expected value of domestic real growth, where Dys is the unanticipated growth component.

- $\quad D p$ is price inflation.

- Denergy is energy price inflation.

- Dreer is the change in the log of the real effective exchange rate.

- $D y^{U S}$ is real output growth in the United States (a proxy for global growth).

- $D y^{M T}$ is real output growth in the major trading partner, Japan.

- $\rho$ is the estimate of the serial correlation parameter. 
Table 3. Determinants of Fluctuations in the Current and Financial Balances: Canada

\begin{tabular}{|c|c|c|c|c|c|c|c|c|c|c|}
\hline Dep Var & Constant & $E D y$ & Dys & $D p$ & Denergy & Dreer & $D y^{u s}$ & $E C$ & $\rho$ & $R^{2}$ \\
\hline Dcbal & $\begin{array}{c}1.27 \\
(0.26)\end{array}$ & $\begin{array}{l}58.6 \\
(0.23)\end{array}$ & $\begin{array}{c}-58.81 \\
(-0.30)\end{array}$ & $\begin{array}{l}-86.56 \\
(-1.29)\end{array}$ & $\begin{array}{l}16.75^{*} \\
(2.04)\end{array}$ & $\begin{array}{c}-36.23 \\
(-0.82)\end{array}$ & $\begin{array}{l}26.02 \\
(1.10)\end{array}$ & $\begin{array}{c}-0.66^{*} \\
(-2.40)\end{array}$ & $\begin{array}{c}-0.58^{*} \\
(-2.37)\end{array}$ & 0.61 \\
\hline Dexport & $\begin{array}{r}-0.034 \\
(-1.09)\end{array}$ & $\begin{array}{c}0.79 \\
(0.51)\end{array}$ & $\begin{array}{c}0.33 \\
(0.26)\end{array}$ & $\begin{array}{l}1.08^{*} \\
(2.64)\end{array}$ & $\begin{array}{c}0.087 \\
(1.66)\end{array}$ & $\begin{array}{c}-0.64^{*} \\
(-2.25)\end{array}$ & $\begin{array}{c}1.95 \\
(1.41)\end{array}$ & & $\begin{array}{c}0.45 \\
(1.57)\end{array}$ & 0.67 \\
\hline Dimport & $\begin{array}{l}-0.058^{*} \\
(-2.00)\end{array}$ & $\begin{array}{c}-0.20 \\
(-0.14)\end{array}$ & $\begin{array}{c}-0.63 \\
(-0.55)\end{array}$ & $\begin{array}{c}1.07 * \\
(2.86)\end{array}$ & $\begin{array}{c}0.054 \\
(1.12)\end{array}$ & $\begin{array}{c}-0.67^{*} \\
(-2.56)\end{array}$ & $\begin{array}{c}3.56^{*} \\
(2.78)\end{array}$ & & $\begin{array}{c}0.79^{*} \\
(4.48)\end{array}$ & 0.73 \\
\hline Dfbal & $\begin{array}{c}-2.30 \\
(-0.37)\end{array}$ & $\begin{array}{r}-120.22 \\
(-0.38)\end{array}$ & $\begin{array}{l}38.51 \\
(0.16)\end{array}$ & $\begin{array}{l}72.74 \\
(0.87)\end{array}$ & $\begin{array}{l}-14.11 \\
(-1.29)\end{array}$ & $\begin{array}{l}42.92 \\
(0.79)\end{array}$ & $\begin{array}{l}83.84 \\
(0.28)\end{array}$ & & $\begin{array}{c}-0.50 \\
(-1.57)\end{array}$ & 0.19 \\
\hline Dinflow & $\begin{array}{c}-0.50 \\
(-1.21)\end{array}$ & $\begin{array}{c}-11.52 \\
(-0.55)\end{array}$ & $\begin{array}{c}-4.35 \\
(-0.27)\end{array}$ & $\begin{array}{c}3.11 \\
(0.58)\end{array}$ & $\begin{array}{c}0.52 \\
(0.75)\end{array}$ & $\begin{array}{c}-2.96 \\
(-0.80)\end{array}$ & $\begin{array}{l}25.53 \\
(1.38)\end{array}$ & & $\begin{array}{c}-0.32 \\
(-1.14)\end{array}$ & 0.25 \\
\hline Doutflow & $\begin{array}{c}0.35 \\
(0.72)\end{array}$ & $\begin{array}{l}-37.81^{*} \\
(-1.96)\end{array}$ & $\begin{array}{c}-0.96 \\
(-0.08)\end{array}$ & $\begin{array}{c}-0.12 \\
(-0.02)\end{array}$ & $\begin{array}{c}0.44 \\
(0.88)\end{array}$ & $\begin{array}{l}-3.68 \\
(-1.46)\end{array}$ & $\begin{array}{l}27.44^{* *} \\
(1.89)\end{array}$ & $\begin{array}{l}0.018^{*} \\
(2.37)\end{array}$ & $\begin{array}{c}0.97 * \\
(4.93)\end{array}$ & 0.49 \\
\hline
\end{tabular}

Notes:

- The dependent variable is in the following order: the first difference of the change in the current account balance, the first difference of the log value of exports, and imports, the first difference of the change in the financial balance, and the first difference of the log value of inflows and outflows.

- $E D y$ is the expected value of domestic real growth, where Dys denotes the unanticipated growth component.

- $\quad D p$ is price inflation.

- Denergy is energy price inflation.

- Dreer is the change in the log of the real effective exchange rate.

- $D y^{U S}$ is real output growth in the United States (a proxy for global growth).

- $E C$ is the error-correction term, the lagged value of the residual in the cointgration regression between non-stationary dependent and explanatory variables.

- $\rho$ is the estimate of the serial correlation parameter. 
Table 4. Determinants of Fluctuations in the Current and Financial Balances: Denmark

\begin{tabular}{|c|c|c|c|c|c|c|c|c|c|c|c|}
\hline Dep Var & Constant & $E D y$ & Dys & $D p$ & Denergy & Dreer & $D y^{u s}$ & $D y^{M T}$ & $E C$ & $\rho$ & $R^{2}$ \\
\hline Dcbal & $\begin{array}{c}3.08 \\
(0.24)\end{array}$ & $\begin{array}{l}49.84 \\
(0.12)\end{array}$ & $\begin{array}{c}-740.62 * \\
(-3.29)\end{array}$ & $\begin{array}{c}-133.4 \\
(-1.67)\end{array}$ & $\begin{array}{l}10.64 \\
(0.84)\end{array}$ & $\begin{array}{c}-2.10 \\
(-0.03)\end{array}$ & $\begin{array}{l}46.01 \\
(0.32)\end{array}$ & $\begin{array}{l}51.73 \\
(0.17)\end{array}$ & & $\begin{array}{c}-0.20 \\
(-0.56)\end{array}$ & 0.39 \\
\hline Dexport & $\begin{array}{l}0.0031 \\
(0.10)\end{array}$ & $\begin{array}{c}0.40 \\
(0.42)\end{array}$ & $\begin{array}{c}0.44 \\
(0.60)\end{array}$ & $\begin{array}{c}0.84 * \\
(3.08)\end{array}$ & $\begin{array}{l}0.091^{*} \\
(2.14)\end{array}$ & $\begin{array}{c}-0.98^{*} \\
(-3.62)\end{array}$ & $\begin{array}{r}0.095 \\
(0.19)\end{array}$ & $\begin{array}{c}1.23 \\
(1.53)\end{array}$ & & $\begin{array}{c}-0.31 \\
(-0.60)\end{array}$ & 0.80 \\
\hline Dimport & $\begin{array}{l}0.0053 \\
(0.11)\end{array}$ & $\begin{array}{c}1.60 \\
(1.12)\end{array}$ & $\begin{array}{c}2.84 * \\
(3.62)\end{array}$ & $\begin{array}{c}0.50 \\
(1.42)\end{array}$ & $\begin{array}{c}0.06 \\
(1.08)\end{array}$ & $\begin{array}{c}-1.21^{*} \\
(-3.54)\end{array}$ & $\begin{array}{c}-0.21 \\
(-0.33)\end{array}$ & $\begin{array}{c}0.66 \\
(0.60)\end{array}$ & & $\begin{array}{c}-0.72 * \\
(-2.88)\end{array}$ & 0.71 \\
\hline Dfbal & $\begin{array}{c}1.14 \\
(0.04)\end{array}$ & $\begin{array}{l}-25.93 \\
(-0.03)\end{array}$ & $\begin{array}{c}1067.68^{* *} \\
(1.79)\end{array}$ & $\begin{array}{r}161.86 \\
(0.72)\end{array}$ & $\begin{array}{l}56.95 \\
(1.63)\end{array}$ & $\begin{array}{r}106.89 \\
(0.48)\end{array}$ & $\begin{array}{c}4.31 \\
(0.01)\end{array}$ & $\begin{array}{c}-490.0 \\
(-0.73)\end{array}$ & & $\begin{array}{c}-0.83^{*} \\
(-2.37)\end{array}$ & 0.086 \\
\hline Dinflow & $\begin{array}{c}-19.74 \\
(-0.17)\end{array}$ & $\begin{array}{r}2041.20 \\
\quad(0.52)\end{array}$ & $\begin{array}{r}597.94 \\
(0.29)\end{array}$ & $\begin{array}{r}-435.2 \\
(-0.56)\end{array}$ & $\begin{array}{r}245.87 \\
(1.45)\end{array}$ & $\begin{array}{c}548.49 \\
(0.54)\end{array}$ & $\begin{array}{c}879.15 \\
(0.60)\end{array}$ & $\begin{array}{r}-1279.3 \\
(-0.43)\end{array}$ & $\begin{array}{c}-0.21 \\
(-0.27)\end{array}$ & $\begin{array}{c}-0.34 \\
(-0.47)\end{array}$ & 0.44 \\
\hline Doutflow & $\begin{array}{l}46.21 \\
(0.37)\end{array}$ & $\begin{array}{r}-2220.82 \\
(-0.55)\end{array}$ & $\begin{array}{l}26.19 \\
(0.01)\end{array}$ & $\begin{array}{r}479.52 \\
(0.59)\end{array}$ & $\begin{array}{r}-209.87 \\
(-1.53)\end{array}$ & $\begin{array}{r}-204.4 \\
\quad(-0.21)\end{array}$ & $\begin{array}{r}-1312.6 \\
(-0.89)\end{array}$ & $\begin{array}{r}667.33 \\
(0.26)\end{array}$ & & $\begin{array}{c}-0.27 \\
(-0.41)\end{array}$ & 0.26 \\
\hline
\end{tabular}

Notes:

- The dependent variable is in the following order: the first difference of the change in the current account balance, the first difference of the log value of exports, and imports, the first difference of the change in the financial balance, and the first difference of the log value of inflows and outflows.

- EDy is the expected value of domestic real growth, where Dys is the unanticipated growth component.

- $\quad D p$ is price inflation.

- Denergy is energy price inflation.

- Dreer is the change in the log of the real effective exchange rate.

- $D y^{U S}$ is real output growth in the United States (a proxy for global growth).

- $D y^{M T}$ is real output growth in the major trading partner, Europe.

- $E C$ is the error-correction term, the lagged value of the residual in the cointgration regression between non-stationary dependent and explanatory variables.

- $\rho$ is the estimate of the serial correlation parameter. 
Table 5. Determinants of Fluctuations in the Current and Financial Balances: France

\begin{tabular}{|c|c|c|c|c|c|c|c|c|c|c|}
\hline Dep Var & Constant & $E D y$ & Dys & $D p$ & Denergy & Dreer & $D y^{u s}$ & $D y^{M T}$ & $\rho$ & $R^{2}$ \\
\hline Dcbal & $\begin{array}{c}0.74 \\
(0.09)\end{array}$ & $\begin{array}{l}42.41 \\
(0.09)\end{array}$ & $\begin{array}{c}-693.07^{*} \\
(-2.87)\end{array}$ & $\begin{array}{l}-50.50 \\
(-1.21)\end{array}$ & $\begin{array}{l}-6.51 \\
(-0.96)\end{array}$ & $\begin{array}{l}64.48 \\
(1.20)\end{array}$ & $\begin{array}{c}184.12 * * \\
(1.74)\end{array}$ & $\begin{array}{r}-139.18 \\
(-0.47)\end{array}$ & $\begin{array}{c}0.40 \\
(1.43)\end{array}$ & 0.12 \\
\hline Dexport & $\begin{array}{r}-0.027 \\
(0.62)\end{array}$ & $\begin{array}{l}-0.66 \\
(-0.24)\end{array}$ & $\begin{array}{c}-0.13 \\
(-0.08)\end{array}$ & $\begin{array}{c}1.31 * \\
(4.75)\end{array}$ & $\begin{array}{r}0.067 \\
(1.49)\end{array}$ & $\begin{array}{l}-0.71^{*} \\
(-2.00)\end{array}$ & $\begin{array}{c}0.63 \\
(0.97)\end{array}$ & $\begin{array}{c}1.60 \\
(0.80)\end{array}$ & $\begin{array}{l}-0.081 \\
(-0.30)\end{array}$ & 0.69 \\
\hline Dfbal & $\begin{array}{l}-6.027 \\
(-0.85)\end{array}$ & $\begin{array}{l}506.7 \\
(1.17)\end{array}$ & $\begin{array}{r}678.62 * \\
(3.83)\end{array}$ & $\begin{array}{l}30.19 \\
(0.69)\end{array}$ & $\begin{array}{l}11.056 \\
(1.54)\end{array}$ & $\begin{array}{l}-40.59 \\
(-0.72)\end{array}$ & $\begin{array}{l}-22.06 \\
(-0.21)\end{array}$ & $\begin{array}{r}-326.17 \\
(-1.02)\end{array}$ & $\begin{array}{c}0.13 \\
(0.48)\end{array}$ & 0.52 \\
\hline Dinflow & $\begin{array}{c}-0.11 \\
(-0.16)\end{array}$ & $\begin{array}{l}30.46 \\
(0.69)\end{array}$ & $\begin{array}{c}6.84 \\
(0.26)\end{array}$ & $\begin{array}{l}-2.45 \\
(-0.54)\end{array}$ & $\begin{array}{c}1.032 \\
(1.39)\end{array}$ & $\begin{array}{c}-0.53 \\
(-0.09)\end{array}$ & $\begin{array}{c}6.40 \\
(0.59)\end{array}$ & $\begin{array}{l}-24.87 \\
(-0.76)\end{array}$ & $\begin{array}{l}-0.94^{*} \\
(-2.85)\end{array}$ & 0.063 \\
\hline
\end{tabular}

Notes:

- The dependent variable is in the following order: the first difference of the change in the current account balance, the first difference of the log value of exports, and imports, the first difference of the change in the financial balance, and the first difference of the log value of inflows and outflows.

- EDy is the expected value of domestic real growth, where Dys is the unanticipated growth component.

- $D p$ is price inflation.

- Denergy is energy price inflation.

- Dreer is the change in the log of the real effective exchange rate.

- $D y^{U S}$ is real output growth in the United States (a proxy for global growth).

- $D y^{M T}$ is real output growth in the major trading partner, Europe.

- $\rho$ is the estimate of the serial correlation parameter. 
Table 6. Determinants of Fluctuations in the Current and Financial Balances: Germany

\begin{tabular}{lcccccccccc}
\hline Dep Var & Constant & $E D y$ & $D y s$ & $D p$ & Denergy & Dreer & $D y^{u s}$ & $D y^{M T}$ & $\rho$ & $R^{2}$ \\
\hline Dcbal & 6.10 & $-1222.22^{* *}$ & -1619.02 & -126.037 & -11.11 & -39.82 & 136.31 & 901.45 & $1.02^{*}$ & 0.32 \\
& $(0.27)$ & $(-1.89)$ & $(-1.47)$ & $(-0.33)$ & $(-0.55)$ & $(-0.65)$ & $(0.55)$ & $(0.80)$ & $(2.8)$ \\
Dexport & 0.07 & -1.56 & -0.26 & -0.23 & 0.076 & -0.23 & -0.14 & 1.42 & 0.099 & 0.32 \\
& $(1.13)$ & $(-0.87)$ & $(-0.10)$ & $(-0.23)$ & $(1.44)$ & $(-1.43)$ & $(-0.22)$ & $(0.48)$ & $(0.84)$ & \\
Dimport & 0.076 & 1.23 & 2.49 & -0.40 & $0.16^{*}$ & -0.16 & -0.71 & -0.57 & -0.011 & 0.62 \\
& $(1.11$ & $(0.63)$ & $(0.81$ & $(-0.36)$ & $(2.67)$ & $(-0.85)$ & $(-0.95)$ & $(-0.18$ & $(-0.10)$ & \\
Dfbal & -10.2 & $200.54^{* *}$ & 2014.48 & 50.77 & 20.61 & 24.99 & -89.76 & -1487.7 & $0 . .51$ & 0.19 \\
& $(-0.27$ & $(1.86)$ & $(1.16)$ & $(0.08)$ & $(0.60)$ & $(0.24)$ & $(-0.21)$ & $(-0.82)$ & $(1.17)$ & \\
Dinflow & -0.86 & 10.71 & -35.86 & 1.33 & -0.14 & -1.60 & 8.28 & 21.08 & -0.45 & 0.35 \\
& $(-1.30)$ & $(0.55)$ & $(-1.27)$ & $(0.15)$ & $(-0.27)$ & $(-1.11)$ & $(1.26)$ & $(0.71)$ & $(-1.14)$ \\
Doutflow & -0.66 & -8.71 & $-52.15 * *$ & 1.21 & 0.05 & -0.33 & 9.06 & 29.39 & -0.51 & 0.24 \\
& $(-1.05)$ & $(-0.46)$ & $(-1.85)$ & $(0.13)$ & $(0.09)$ & $(-0.21)$ & $(1.36)$ & $(0.99)$ & $(-1.53)$ \\
\hline
\end{tabular}

Notes:

- The dependent variable is in the following order: the first difference of the change in the current account balance, the first difference of the log value of exports, and imports, the first difference of the change in the financial balance, and the first difference of the log value of inflows and outflows.

- EDy is the expected value of domestic real growth, where Dys is the unanticipated growth component.

- $D p$ is price inflation.

- Denergy is energy price inflation.

- Dreer is the change in the log of the real effective exchange rate.

- $D y^{U S}$ is real output growth in the United States (a proxy for global growth).

- $D y^{M T}$ is real output growth in the major trading partner, Europe.

- $\rho$ is the estimate of the serial correlation parameter. 
Table 7. Determinants of Fluctuations in the Current and Financial Balances: Italy

\begin{tabular}{|c|c|c|c|c|c|c|c|c|c|c|}
\hline Dep Var & Constant & $E D y$ & $D y s$ & $D p$ & Denergy & Dreer & $D y^{u s}$ & $D y^{M T}$ & $\rho$ & $R^{2}$ \\
\hline Dcbal & $\begin{array}{l}16.98^{*} \\
(1.95)\end{array}$ & $\begin{array}{l}-47.06 \\
(-0.17)\end{array}$ & $\begin{array}{c}545.16^{*} \\
(2.08)\end{array}$ & $\begin{array}{l}-16.81 \\
(-0.34)\end{array}$ & $\begin{array}{c}1.78 \\
(0.17)\end{array}$ & $\begin{array}{c}6.97 \\
(0.27)\end{array}$ & $\begin{array}{c}-84.24 \\
(-0.75)\end{array}$ & $\begin{array}{r}-573.84^{*} \\
(-2.26)\end{array}$ & $\begin{array}{r}0.95^{*} \\
(12.02)\end{array}$ & 0.38 \\
\hline Dexport & $\begin{array}{l}-0.021 \\
(-0.34)\end{array}$ & $\begin{array}{l}-0.34 \\
(-0.14)\end{array}$ & $\begin{array}{l}-0.19 \\
(-0.07)\end{array}$ & $\begin{array}{c}1.01 * \\
(2.46)\end{array}$ & $\begin{array}{l}-0.011 \\
(-0.10)\end{array}$ & $\begin{array}{l}-0.26 \\
(-0.96)\end{array}$ & $\begin{array}{c}1.41 \\
(1.42)\end{array}$ & $\begin{array}{c}0.66 \\
(0.26)\end{array}$ & $\begin{array}{c}0.26 \\
(0.66)\end{array}$ & 0.66 \\
\hline Dimport & $\begin{array}{c}-0.04 \\
(-0.79)\end{array}$ & $\begin{array}{c}0.64 \\
(0.29)\end{array}$ & $\begin{array}{c}2.85 \\
(1.47)\end{array}$ & $\begin{array}{l}1.014^{*} \\
(2.77)\end{array}$ & $\begin{array}{l}0.18^{*} \\
(2.05)\end{array}$ & $\begin{array}{c}-0.55^{*} \\
(-2.49)\end{array}$ & $\begin{array}{r}1.076 \\
(1.28)\end{array}$ & $\begin{array}{c}0.96 \\
(0.46)\end{array}$ & $\begin{array}{l}-0.052 \\
(-0.23)\end{array}$ & 0.78 \\
\hline Dfbal & $\begin{array}{l}-12.28 \\
(-1.04)\end{array}$ & $\begin{array}{c}359.92 \\
(0.83)\end{array}$ & $\begin{array}{r}-338.55 \\
(-0.75)\end{array}$ & $\begin{array}{l}-1.80 \\
(-0.02)\end{array}$ & $\begin{array}{l}-20.16 \\
(-1.11)\end{array}$ & $\begin{array}{l}-3.33 \\
(-0.07)\end{array}$ & $\begin{array}{l}-25.87 \\
(-0.15)\end{array}$ & $\begin{array}{r}287.35 \\
(0.67)\end{array}$ & $\begin{array}{l}-0.41 \\
(-1.13)\end{array}$ & 0.001 \\
\hline Dinflow & $\begin{array}{l}35.53 \\
(0.20)\end{array}$ & $\begin{array}{r}-1800.09 \\
(-0.22)\end{array}$ & $\begin{array}{l}-16.08 \\
(-0.84)\end{array}$ & $\begin{array}{c}25.88^{*} \\
(2.76)\end{array}$ & $\begin{array}{c}-0.61 \\
(-0.61)\end{array}$ & $\begin{array}{c}0.10 \\
(0.05)\end{array}$ & $\begin{array}{c}27.53^{*} \\
(2.85)\end{array}$ & $\begin{array}{c}2.86 \\
(0.14)\end{array}$ & $\begin{array}{r}0.085 \\
(0.19)\end{array}$ & 0.59 \\
\hline Doutflow & $\begin{array}{l}29.32 \\
(0.30)\end{array}$ & $\begin{array}{r}-1563.33 \\
(-0.34)\end{array}$ & $\begin{array}{l}-33.82 \\
(-1.16)\end{array}$ & $\begin{array}{l}34.99 * * \\
(2.51)\end{array}$ & $\begin{array}{l}-2.037 \\
(-1.37)\end{array}$ & $\begin{array}{c}3.62 \\
(1.10)\end{array}$ & $\begin{array}{l}39.48^{*} \\
(2.74)\end{array}$ & $\begin{array}{l}10.35 \\
(0.35)\end{array}$ & $\begin{array}{c}-0.13 \\
(-0.31)\end{array}$ & 0.45 \\
\hline
\end{tabular}

Notes:

- The dependent variable is in the following order: the first difference of the change in the current account balance, the first difference of the log value of exports, and imports, the first difference of the change in the financial balance, and the first difference of the log value of inflows and outflows.

- EDy is the expected value of domestic real growth, where Dys is the unanticipated growth component.

- $D p$ is price inflation.

- Denergy is energy price inflation.

- Dreer is the change in the log of the real effective exchange rate.

- $D y^{U S}$ is real output growth in the United States (a proxy for global growth).

- $D y^{M T}$ is real output growth in the major trading partner, Europe.

- $\rho$ is the estimate of the serial correlation parameter. 
Table 8. Determinants of Fluctuations in the Current and Financial Balances: New Zealand

\begin{tabular}{|c|c|c|c|c|c|c|c|c|c|c|c|}
\hline Dep Var & Constant & $E D y$ & Dys & $D p$ & Denergy & Dreer & $D y^{u s}$ & $D y^{M T}$ & $E C$ & $\rho$ & $R^{2}$ \\
\hline Dcbal & $\begin{array}{l}-0.16 \\
(-0.12)\end{array}$ & $\begin{array}{l}10.50 \\
(0.23)\end{array}$ & $\begin{array}{l}-45.08^{* *} \\
(-1.86)\end{array}$ & $\begin{array}{l}-2.30 \\
(-0.31)\end{array}$ & $\begin{array}{l}-2.08 \\
(-1.41)\end{array}$ & $\begin{array}{c}2.37 \\
(0.34)\end{array}$ & $\begin{array}{c}-14.14 \\
(-0.57)\end{array}$ & $\begin{array}{c}7.39 \\
(0.26)\end{array}$ & & $\begin{array}{c}-0.29 \\
(-1.07)\end{array}$ & 0.39 \\
\hline Dexport & $\begin{array}{l}-0.029 \\
(-0.68)\end{array}$ & $\begin{array}{l}2.68 * * \\
(1.86)\end{array}$ & $\begin{array}{l}1.23 * * \\
(1.81)\end{array}$ & $\begin{array}{c}0.98^{*} \\
(4.75)\end{array}$ & $\begin{array}{c}0.11 * \\
(2.79)\end{array}$ & $\begin{array}{l}-0.75^{*} \\
(-3.90)\end{array}$ & $\begin{array}{c}-0.15 \\
(-0.23)\end{array}$ & $\begin{array}{l}-0.092 \\
(-0.12)\end{array}$ & & $\begin{array}{l}-0.44 * \\
(-2.75)\end{array}$ & 0.72 \\
\hline Dimport & $\begin{array}{l}-0.0054 \\
(-0.13)\end{array}$ & $\begin{array}{c}1.51 \\
(1.18)\end{array}$ & $\begin{array}{c}2.58^{*} \\
(3.08)\end{array}$ & $\begin{array}{c}0.86^{*} \\
(3.33)\end{array}$ & $\begin{array}{c}0.12 * \\
(2.27)\end{array}$ & $\begin{array}{l}-1.02^{*} \\
(-4.52)\end{array}$ & $\begin{array}{c}-1.26 \\
(-1.48)\end{array}$ & $\begin{array}{c}1.16 \\
(1.20)\end{array}$ & & $\begin{array}{c}-0.33 \\
(-1.20)\end{array}$ & 0.76 \\
\hline Dfbal & $\begin{array}{c}1.94 \\
(0.68)\end{array}$ & $\begin{array}{l}-6.21 \\
(-0.07)\end{array}$ & $\begin{array}{l}47.5 \\
(0.80)\end{array}$ & $\begin{array}{c}0.14 \\
(0.01)\end{array}$ & $\begin{array}{c}2.61 \\
(0.71)\end{array}$ & $\begin{array}{l}-8.15 \\
(-0.50)\end{array}$ & $\begin{array}{l}47.39 \\
(0.76)\end{array}$ & $\begin{array}{l}-89.31 \\
(-1.29)\end{array}$ & & $\begin{array}{c}-0.30 \\
(-0.85)\end{array}$ & 0.22 \\
\hline Dinflow & $\begin{array}{c}0.31 \\
(0.10)\end{array}$ & $\begin{array}{l}19.15 \\
(0.20)\end{array}$ & $\begin{array}{l}64.58 \\
(0.99)\end{array}$ & $\begin{array}{l}17.35 \\
(0.86)\end{array}$ & $\begin{array}{l}4.076 \\
(1.03)\end{array}$ & $\begin{array}{l}-31.8 * * \\
(-1.83)\end{array}$ & $\begin{array}{l}13.82 \\
(0.21)\end{array}$ & $\begin{array}{l}-55.53 \\
(-0.74)\end{array}$ & & $\begin{array}{l}-0.028 \\
(-0.06)\end{array}$ & 0.4 \\
\hline Doutflow & $\begin{array}{l}-38.74 \\
(-0.44)\end{array}$ & $\begin{array}{r}1638.73 \\
(0.50)\end{array}$ & $\begin{array}{c}-6.69 \\
(-0.17)\end{array}$ & $\begin{array}{l}-79.12 * \\
(-2.01)\end{array}$ & $\begin{array}{c}0.996 \\
(0.43)\end{array}$ & $\begin{array}{l}-29.28 * \\
(-2.41)\end{array}$ & $\begin{array}{l}-32.57 \\
(-0.83)\end{array}$ & $\begin{array}{l}16.16 \\
(0.38)\end{array}$ & $\begin{array}{l}-0.001 * \\
(-4.40)\end{array}$ & $\begin{array}{c}-0.14 \\
(-0.16)\end{array}$ & 0.45 \\
\hline
\end{tabular}

Notes:

- The dependent variable is in the following order: the first difference of the change in the current account balance, the first difference of the log value of exports, and imports, the first difference of the change in the financial balance, and the first difference of the log value of inflows and outflows.

- EDy is the expected value of domestic real growth, where Dys is the unanticipated growth component.

- $D p$ is price inflation.

- Denergy is energy price inflation.

- Dreer is the change in the log of the real effective exchange rate.

- $D y^{U S}$ is real output growth in the United States (a proxy for global growth).

- $D y^{M T}$ is real output growth in the major trading partner, Australia.

- $E C$ is the error-correction term, the lagged value of the residual in the cointgration regression between non-stationary dependent and explanatory variables.

- $\rho$ is the estimate of the serial correlation parameter. 
Table 9. Determinants of Fluctuations in the Current and Financial Balances: Sweden

\begin{tabular}{|c|c|c|c|c|c|c|c|c|c|c|}
\hline Dep Var & Constant & $E D y$ & Dys & $D p$ & Denergy & Dreer & $D y^{u s}$ & $D y^{M T}$ & $\rho$ & $R^{2}$ \\
\hline Dcbal & $\begin{array}{c}9.83 \\
(0.68)\end{array}$ & $\begin{array}{c}645.9 \\
(1.45)\end{array}$ & $\begin{array}{c}681.62 \\
(1.41)\end{array}$ & $\begin{array}{l}-32.04 \\
(-0.25)\end{array}$ & $\begin{array}{c}-14.49 \\
(-0.58)\end{array}$ & $\begin{array}{l}32.71 \\
(0.40)\end{array}$ & $\begin{array}{l}54.0 \\
(0.15)\end{array}$ & $\begin{array}{l}-878.12^{* *} \\
(-1.86)\end{array}$ & $\begin{array}{c}0.87 * \\
(3.07)\end{array}$ & 0.33 \\
\hline Dexport & $\begin{array}{l}0.0015 \\
(0.03)\end{array}$ & $\begin{array}{c}-0.62 \\
(-0.39)\end{array}$ & $\begin{array}{c}3.28^{*} \\
(3.21)\end{array}$ & $\begin{array}{c}0.99 * \\
(2.72)\end{array}$ & $\begin{array}{l}0.097 * \\
(1.96)\end{array}$ & $\begin{array}{l}-0.47^{*} \\
(-2.17)\end{array}$ & $\begin{array}{c}2.45 * \\
(2.38)\end{array}$ & $\begin{array}{l}-1.08 \\
(-0.89)\end{array}$ & $\begin{array}{c}0.82 * \\
(2.64)\end{array}$ & 0.54 \\
\hline Dimport & $\begin{array}{l}0.0072 \\
(0.08)\end{array}$ & $\begin{array}{c}0.43 \\
(0.19)\end{array}$ & $\begin{array}{c}4.17 * \\
(2.43)\end{array}$ & $\begin{array}{c}0.54 \\
(0.74)\end{array}$ & $\begin{array}{c}0.10 \\
(1.20)\end{array}$ & $\begin{array}{l}-0.64 * * \\
(-1.90)\end{array}$ & $\begin{array}{c}0.34 \\
(0.24)\end{array}$ & $\begin{array}{c}1.24 \\
(0.64)\end{array}$ & $\begin{array}{l}-0.41^{*} \\
(-2.00)\end{array}$ & 0.65 \\
\hline Dfbal & $\begin{array}{c}-79.61 * \\
(-2.01)\end{array}$ & $\begin{array}{r}-951.85 \\
(-0.77)\end{array}$ & $\begin{array}{r}382.74 \\
(0.29)\end{array}$ & $\begin{array}{c}356.15 \\
(1.01)\end{array}$ & $\begin{array}{l}32.40 \\
(0.47)\end{array}$ & $\begin{array}{r}-397.2 * * \\
(-1.74)\end{array}$ & $\begin{array}{r}282.84 \\
(0.29)\end{array}$ & $\begin{array}{r}2936.86^{*} \\
(2.29)\end{array}$ & $\begin{array}{c}-0.21 \\
(-0.69)\end{array}$ & 0.082 \\
\hline Dinflow & $\begin{array}{c}-153.01 \\
(-1.54)\end{array}$ & $\begin{array}{r}1980.19 \\
(0.65)\end{array}$ & $\begin{array}{r}-164.53 \\
(-0.05)\end{array}$ & $\begin{array}{c}360.50 \\
(0.42)\end{array}$ & $\begin{array}{l}-75.71 \\
(-0.46)\end{array}$ & $\begin{array}{r}-216.05 \\
(-0.39)\end{array}$ & $\begin{array}{r}3422.92 \\
(1.43)\end{array}$ & $\begin{array}{c}-523.98 \\
(-0.17)\end{array}$ & $\begin{array}{r}-0.17 \\
(.0 .42)\end{array}$ & 0.12 \\
\hline Doutflow & $\begin{array}{r}151.27 \\
(1.58)\end{array}$ & $\begin{array}{r}-2190.25 \\
(-0.74)\end{array}$ & $\begin{array}{r}-2427.21 \\
(-0.77)\end{array}$ & $\begin{array}{r}-691.28 \\
(-0.82)\end{array}$ & $\begin{array}{l}-21.44 \\
(-0.13)\end{array}$ & $\begin{array}{r}154.88 \\
(0.28)\end{array}$ & $\begin{array}{r}-3783.6 \\
(-1.63)\end{array}$ & $\begin{array}{r}2158.23 \\
(0.69)\end{array}$ & $\begin{array}{c}0.20 \\
(-0.53)\end{array}$ & 0.07 \\
\hline
\end{tabular}

Notes:

- The dependent variable is in the following order: the first difference of the exchange in the current account balance, the first difference of the log value of exports, and imports, the first difference of the change in the financial balance, and the first difference of the log value of inflows and outflows.

- EDy is the expected value of domestic real growth, where Dys is the unanticipated growth component.

- $D p$ is price inflation.

- Denergy is energy price inflation

- Dreer is the change in the log of the real effective exchange rate.

- $D y^{U S}$ is real output growth in the United States (a proxy for global growth).

- $D y^{M T}$ is real output growth in the major trading partner, Europe.

- $\rho$ is the estimate of the serial correlation parameter. 
Table 10. Determinants of Fluctuations in the Current and Financial Balances: United Kingdom

\begin{tabular}{|c|c|c|c|c|c|c|c|c|c|c|}
\hline Dep Var & Constant & $E D y$ & Dys & $D p$ & Denergy & Dreer & $D y^{u s}$ & $D y^{M T}$ & $\rho$ & $R^{2}$ \\
\hline Dcbal & $\begin{array}{c}-0.47 \\
(-0.07)\end{array}$ & $\begin{array}{c}136.7 \\
(0.56)\end{array}$ & $\begin{array}{l}-67.52 \\
(-0.34)\end{array}$ & $\begin{array}{l}36.52 \\
(0.54)\end{array}$ & $\begin{array}{l}-7.20 \\
(-0.60)\end{array}$ & $\begin{array}{l}31.06 \\
(0.89)\end{array}$ & $\begin{array}{c}-92.07 \\
(-0.63)\end{array}$ & $\begin{array}{r}-122.29 \\
(-0.49)\end{array}$ & $\begin{array}{c}-0.03 \\
(-1.10)\end{array}$ & 0.37 \\
\hline Dexport & $\begin{array}{l}0.00043 \\
(0.02)\end{array}$ & $\begin{array}{l}1.75^{* *} \\
(1.84)\end{array}$ & $\begin{array}{c}0.65 \\
(0.78)\end{array}$ & $\begin{array}{c}0.99^{*} \\
(3.71)\end{array}$ & $\begin{array}{c}0.14^{*} \\
(3.06)\end{array}$ & $\begin{array}{c}-0.36^{*} \\
(-2.55)\end{array}$ & $\begin{array}{c}0.54 \\
(0.98)\end{array}$ & $\begin{array}{c}-1.46 \\
(-1.49)\end{array}$ & $\begin{array}{c}-0.30 \\
(-0.65)\end{array}$ & 0.69 \\
\hline Dimport & $\begin{array}{c}-0.016 \\
(-0.37)\end{array}$ & $\begin{array}{c}2.81^{*} \\
(1.95)\end{array}$ & $\begin{array}{c}-0.76 \\
(-0.57)\end{array}$ & $\begin{array}{c}0.63 \\
(1.46)\end{array}$ & $\begin{array}{c}0.14^{*} \\
(2.07)\end{array}$ & $\begin{array}{c}-0.26 \\
(-1.16)\end{array}$ & $\begin{array}{c}0.40 \\
(0.47)\end{array}$ & $\begin{array}{c}-1.29 \\
(-0.86)\end{array}$ & $\begin{array}{c}-0.43 \\
(-1.34)\end{array}$ & -0.52 \\
\hline Dfbal & $\begin{array}{c}-8964 * \\
(-5.94)\end{array}$ & $\begin{array}{l}394604.7 \\
\quad(1.77 \mathrm{E} 24)\end{array}$ & $\begin{array}{c}6.77 \\
(0.02)\end{array}$ & $\begin{array}{r}127.38 \\
(0.87)\end{array}$ & $\begin{array}{l}-3.05 \\
(-0.20)\end{array}$ & $\begin{array}{l}-26.41 \\
(-0.53)\end{array}$ & $\begin{array}{r}206.84 \\
(0.86)\end{array}$ & $\begin{array}{r}422.06 \\
(1.11)\end{array}$ & $\begin{array}{c}-0.39 \\
(-1.01)\end{array}$ & 0.099 \\
\hline Dinflow & $\begin{array}{l}14.6 \\
(0.17)\end{array}$ & $\begin{array}{r}762.56 \\
(0.25)\end{array}$ & $\begin{array}{c}-1560.36 \\
(-0.53)\end{array}$ & $\begin{array}{r}-827.76 \\
(-0.88)\end{array}$ & $\begin{array}{c}220.21 \\
(1.56)\end{array}$ & $\begin{array}{c}220.77 \\
(0.38)\end{array}$ & $\begin{array}{r}-1290.1 \\
(-0.58)\end{array}$ & $\begin{array}{r}2038.18 \\
(0.64)\end{array}$ & $\begin{array}{c}-0.38 \\
(-0.72)\end{array}$ & 0.25 \\
\hline Doutflow & $\begin{array}{l}-14.73 \\
(-0.17)\end{array}$ & $\begin{array}{r}-892.8 \\
(-0.30)\end{array}$ & $\begin{array}{r}1823.5 \\
(0.64)\end{array}$ & $\begin{array}{r}802.43 \\
(0.86)\end{array}$ & $\begin{array}{r}-213.78 \\
(-1.54)\end{array}$ & $\begin{array}{r}-280.83 \\
(-0.49)\end{array}$ & $\begin{array}{r}1225.94 \\
(0.57)\end{array}$ & $\begin{array}{c}-1671.67 \\
(-0.54)\end{array}$ & $\begin{array}{c}-0.31 \\
(-0.59)\end{array}$ & 0.26 \\
\hline
\end{tabular}

Notes:

- The dependent variable is in the following order: the first difference of the change in the current account balance, the first difference of the log value of exports, and imports, the first difference of the change in the financial balance, and the first difference of the log value of inflows and outflows.

- $E D y$ is the expected value of domestic real growth, where Dys is the unanticipated growth component.

- $\quad D p$ is price inflation.

- Denergy is energy price inflation.

- Dreer is the change in the log of the real effective exchange rate.

- $D y^{U S}$ is real output growth in the United States (a proxy for global growth).

- $D y^{M T}$ is real output growth in the major trading partner, Europe.

- $\rho$ is the estimate of the serial correlation parameter. 
Table 11. Correlation Between Changes in the Current and Financial Balances and Underlying Components

\begin{tabular}{|c|c|c|c|c|c|c|c|c|c|}
\hline Country & $\begin{array}{c}\text { Corr Dcbal } \\
\text { Dfbal }\end{array}$ & $\begin{array}{c}\text { Corr Dcbal } \\
\text { Dinfl }\end{array}$ & $\begin{array}{c}\text { Corr Dcbal } \\
\text { Doutfl }\end{array}$ & $\begin{array}{c}\text { Corr Dcba } \\
\text { Dexp }\end{array}$ & $\begin{array}{c}\text { Corr Dfbal } \\
\text { Dimp }\end{array}$ & $\begin{array}{c}\text { Corr Dfbal } \\
\text { Dinfl }\end{array}$ & $\begin{array}{c}\text { Corr Dfbal } \\
\text { Doutfl }\end{array}$ & $\begin{array}{c}\text { Corr Dfbal } \\
\text { Dexp }\end{array}$ & $\begin{array}{c}\text { Corr Dfbal } \\
\text { Dimp }\end{array}$ \\
\hline Australia & $\begin{array}{l}-0.96^{*} \\
(0.0001)\end{array}$ & $\begin{array}{c}0.23 \\
(0.27)\end{array}$ & $\begin{array}{c}0.42 * \\
(0.041)\end{array}$ & $\begin{array}{c}0.44 * \\
(0.032)\end{array}$ & $\begin{array}{l}-0.33 \\
(0.12)\end{array}$ & $\begin{array}{l}0.28 \\
(0.18)\end{array}$ & $\begin{array}{l}-0.42^{*} \\
(0.039)\end{array}$ & $\begin{array}{l}-0.46^{*} \\
(0.025)\end{array}$ & $\begin{array}{l}0.28 \\
(0.17)\end{array}$ \\
\hline Canada & $\begin{array}{l}-0.86^{*} \\
(0.0001)\end{array}$ & $\begin{array}{c}0.16 \\
(0.43)\end{array}$ & $\begin{array}{c}0.13 \\
(0.50)\end{array}$ & $\begin{array}{c}0.23 \\
(0.26)\end{array}$ & $\begin{array}{l}-0.24 \\
(0.22)\end{array}$ & $\begin{array}{l}0.39^{*} \\
(0.0460)\end{array}$ & $\begin{array}{l}0.054 \\
(0.79)\end{array}$ & $\begin{array}{l}-0.13 \\
(0.53)\end{array}$ & $\begin{array}{l}0.31 \\
(0.11)\end{array}$ \\
\hline France & $\begin{array}{l}-0.84 * \\
(0.0001)\end{array}$ & $\begin{array}{c}0.082 \\
(0.68)\end{array}$ & $\begin{array}{c}0.19 \\
(0.35)\end{array}$ & $\begin{array}{l}-0.19 \\
(0.33)\end{array}$ & $\begin{array}{l}-0.41^{*} \\
(0.010)\end{array}$ & $\begin{array}{l}0.078 \\
(0.70)\end{array}$ & $\begin{array}{l}-0.036 \\
(0.86)\end{array}$ & $\begin{array}{l}0.11 \\
(0.60)\end{array}$ & $\begin{array}{l}0.39^{*} \\
(0.046)\end{array}$ \\
\hline Germany & $\begin{array}{l}-0.85^{*} \\
(0.0001)\end{array}$ & $\begin{array}{l}-0.069 \\
(0.73)\end{array}$ & $\begin{array}{c}0.24 \\
(0.23)\end{array}$ & $\begin{array}{r}0.025 \\
(0.90)\end{array}$ & $\begin{array}{l}-0.49^{*} \\
(0.010)\end{array}$ & $\begin{array}{l}0.17 \\
(0.40)\end{array}$ & $\begin{array}{l}-0.13 \\
(0.53)\end{array}$ & $\begin{array}{l}0.045 \\
(0.82)\end{array}$ & $\begin{array}{l}0.44^{*} \\
(0.022)\end{array}$ \\
\hline Sweden & $\begin{array}{l}-0.49^{*} \\
(0.010)\end{array}$ & $\begin{array}{l}-0.17 \\
(0.41)\end{array}$ & $\begin{array}{l}-0.10 \\
(0.62)\end{array}$ & $\begin{array}{c}0.38^{*} \\
(0.052)\end{array}$ & $\begin{array}{l}-0.028 \\
(0.89)\end{array}$ & $\begin{array}{l}0.026 \\
(0.90)\end{array}$ & $\begin{array}{l}0.06 \\
(0.77)\end{array}$ & $\begin{array}{l}0.052 \\
(0.80)\end{array}$ & $\begin{array}{l}0.23 \\
(0.25)\end{array}$ \\
\hline U.K. & $\begin{array}{l}-0.58^{*} \\
(0.0016)\end{array}$ & $\begin{array}{l}-0.16 \\
(0.42)\end{array}$ & $\begin{array}{c}0.12 \\
(0.54)\end{array}$ & $\begin{array}{c}0.071 \\
(0.72) \\
\end{array}$ & $\begin{array}{l}-0.30 \\
(0.13)\end{array}$ & $\begin{array}{l}0.16 \\
(0.43)\end{array}$ & $\begin{array}{l}-0.088 \\
(0.66)\end{array}$ & $\begin{array}{l}-0.095 \\
(0.64)\end{array}$ & $\begin{array}{l}0.16 \\
(0.42)\end{array}$ \\
\hline
\end{tabular}

Notes:

- $\operatorname{Corr}($.$) denotes correlation coefficients.$

- Dcbal is the change in the current account balance.

- Dfbal is the change in the financial account balance.

- Dexp is the change in the log value of exports.

- Dimp is the change in the log value of imports.

- Dinfl is the change in the log value of inflows.

- Doutfl is the change in the log value of outflows.

- Bracketed magnitudes denote the probabilty of zero correlation. 
Table 12 A. Correlation Between the Responses of Financial and Current Accounts to Various Shifts within Countries

\begin{tabular}{|c|c|c|c|c|c|c|c|c|c|c|}
\hline Correlation & Australia & Canada & Denmark & France & Germany & Italy & $\begin{array}{c}\text { New } \\
\text { Zealand }\end{array}$ & Sweden & $\begin{array}{c}\text { United } \\
\text { Kingdom }\end{array}$ & $\begin{array}{c}\text { All } \\
\text { Countries }\end{array}$ \\
\hline Coefficient & -0.99 & -0.66 & -0.92 & -0.70 & -0.99 & -0.80 & -0.69 & -0.81 & -0.46 & -0.85 \\
\hline $\begin{array}{l}\text { Probability } \\
\text { of Zero } \\
\text { Correlation }\end{array}$ & $(0.0001)$ & $(0.16)$ & $(0.0029)$ & $(0.08)$ & $(0.0001)$ & $(0.31)$ & $(0.084)$ & $(0.025)$ & $(0.30)$ & $(0.0001)$ \\
\hline
\end{tabular}

Table 12 B. Correlation Between the Responses of Financial and Current Accounts to Various Shifts Across Countries

\begin{tabular}{|c|c|c|c|c|c|c|c|}
\hline Correlation & $E D y$ & Dys & $D p$ & Denergy & Dreer & $D y^{u s}$ & $D y^{M T}$ \\
\hline Coefficient & -0.97 & -0.88 & -0.31 & -0.30 & -0.48 & -0.0015 & -0.87 \\
\hline $\begin{array}{l}\text { Probability } \\
\text { of Zero } \\
\text { Correlation }\end{array}$ & $(0.0001)$ & $(0.002)$ & $(0.41)$ & $(0.43)$ & $(0.18)$ & $(0.99)$ & $(0.0049)$ \\
\hline
\end{tabular}

Notes:

- EDy is the expected value of domestic real growth, where Dys is the unanticipated growth component.

- $\quad D p$ is price inflation.

- Denergy is energy price inflation.

- Dreer is the change in real effective exchange rate.

- $D y^{U S}$ is real output growth in the United States (a proxy for global growth).

- $D y^{M T}$ is real output growth in major trading partners.

- Bracketed magnitudes denote the probability of zero correlation. 


\section{ECONOMETRIC METHODOLOGY}

To estimate the empirical models in (1), we form a proxy for forecasted growth in real GDP. Following the endogeneity test suggested by Engle (1982), anticipated changes are generated by regressing the first difference of the log of real GDP on a constant, two lags of its own, two lags of the first-difference of the log values of the GDP deflator, the energy price, the real effective exchange rate, and government expenditure. Going through a model reduction procedure, the least significant variables are eliminated ('general to specific approach'). The variables kept in the equation are significant at least at the 10 level. Shocks to real growth are generated by subtracting these forecasts from the actual values of these variables.

The maintained hypothesis for estimation is that agents are rational and that the information set used to specify the proxy for expectation is the same as the set used by agents. Given these assumptions, Pagan $(1984,1986)$ showed that the use of regression proxies requires an adjustment of the covariance matrix of the estimators of the model's parameters. Accordingly, the expectation equations are jointly estimated with the rest of the model using 3SLS. The instrument list for estimation includes two lags of the first difference of a representative of the short-term interest rate and two lags of the first-difference of the log value of real GDP, the GDP deflator, the energy price, the real effective exchange rate, real GDP in the United States, real GDP in major trading partners, the money supply, and government spending.

The results of Engle's (1982) test for serial correlation are consistent with the hypothesis that the error term in the estimated empirical model is serially correlated in some cases. To filter out serial correlation, the empirical models are multiplied by the filter $(1-\rho L)$, where $\rho$ is the serial correlation parameter and $L$ is the lag operator. Reported estimates are after transformation to eliminate serial correlation. The error terms in the transformed models are serially uncorrelated. 


\section{DATA DESCRIPTION AND SOURCES}

The following data come from the International Financial Statistics (IFS) data base:

1. Exchange rate: real effective exchange rate and bilateral nominal exchange between the national currency and the United States dollar.

2. Output: real GDP in national currency in billions.

3. Price: GDP deflator.

4. Energy Price: nominal price in United States dollars.

5. United States output: real United States GDP in billions of United States dollars.

6. Australia output: real Australian GDP in billions of Australian dollars .

7. Output in the euro area: A series of real Euro area GDP was constructed by linking two series: one from Fayan, Henry, and Mestry (2001), starting in 1970, and one from the European Central Bank's Monetary Policy Stance Division (1980 to 2002).

8. Japan output: index of real GDP in Japan.

9. Government spending: real central government total expenditure and net lending in billions of national currency.

10. Interest rate: representatives of short-term interest rates.

11. Balance of payments data:

(a) Current account balance in billions of national currency.

(b) Exports of goods and services in billions of national currency.

(c) Financial account balance in billions of national currency.

(d) Inflows in the financial account in national currency.

(e) Outflows in the financial account in national currency.

Inflows comprise direct investment in the country, portfolio investment liabilities, financial derivative liabilities (if available), and other investment liabilities. Outflows are defined as the sum of direct investment abroad, portfolio investment assets, financial derivative assets (if available), and other investment assets.

The series for financial derivatives exist only partly. If available they enter the inflows/outflows series.

\section{Conversion into national currency}

The subseries of balance of payments data are converted into national currency by using the bilateral exchange rate between the United States dollar and the national currency. To convert data series into euros, an artificial euro series was created for France, Italy, and Germany before the euro was introduced in January of 1999. The bilateral exchange rate between the UNITED STATES dollar and the respective national currency before the start of the European Economic and Monetary Union (EMU) was multiplied with the conversion rate with which the countries entered EMU. 


\section{REFERENCES}

Ahmed, Shagil, and Jae Ha Park, 1994, "Sources of Macroeconomic Fluctuations in Small Open Economies," Journal of Macroeconomics, Vol. 16, No. 1, pp. 1-36.

Arora, Vivek, Steven Dunaway, and Hamid Faruqee, 2001, "Sustainability of the United States External Current Account Deficit," in United States: Selected Issues, IMF Country Report 01/149 (Washington: International Monetary Fund, August), pp. 25-39.

Baxter, Marianne, 1995, "International Trade and Business Cycles," in Handbook of International Economics, ed. by Gene M. Grossman and Kenneth Rogoff (Amsterdam et al.: Elsevier), pp. 1801-1864.

Bergin, R. Paul, and Steven M. Sheffrin, 2000, "Interest Rates, Exchange Rates, and Present Value Models of the Current Account," The Economic Journal, Vol. 110, No. 463, pp. 535-558.

Billmeier, Andreas, 2002, "Current Account Fluctuations: How Important are Nominal Shocks?" (Unpublished Manuscript, Florence: European University Institute).

Blanchard, Oliver J., and Danny Quah, 1989, “The Dynamic Effects of Aggregate Demand and Supply Disturbances," American Economic Review, Vol. 79, No. 4, pp. 655-73.

Bussière, M., M. Fratzscher, and G.J. Müller, 2004, "Current Account Dynamics in OECD and EU Acceding Countries - An Intertemporal Approach,” ECB Working Paper No. 311 (Frankfurt: European Central Bank).

Chari, V. V., Patrick J. Kehoe, and Ellen R. McGrattan, 1998, "Sticky Price Models of the Business Cycle: Can the Contract Multiplier Solve the Persistence Problem?" Federal Reserve Bank of Minneapolis, Staff Report 217.

__ 2001, "Can Sticky Price Models Generate Volatile and Persistent Real Exchange Rates?" Federal Reserve Bank of Minneapolis, Staff Report No. 277.

Chinn, Menzie D., and Eswar S. Prasad, 2000, "Medium-Term Determinants of Current Accounts in Industrial and Developing Countries: An Empirical Exploration," IMF Working Paper No. 00/46 (Washington: International Monetary Fund).

Clarida, Richard, and Jordi Gali, 1994, "Sources of Real Exchange Rate Fluctuations: How Important Are Nominal Shocks?" Carnegie Rochester Conference Series on Public Policy, Vol. 41, No. 0, pp.1-56.

Cooper, Richard N., 2001, "Is the United States Current Account: Deficit Sustainable? Will It Be Sustained?" Brookings Papers on Economic Activity, No. 1, pp. 217-26. 
Davidson, Russel, and James G. MacKinnon, 1993, Estimation and Inference in Econometrics (Oxford: Oxford University Press).

Dickey, David A., 1976, "Estimation and Hypothesis Testing in Nonstationary Time Series," (Unpublished doctoral dissertation, Ames, Iowa: University of Iowa).

— with a Unit Root," Econometrica, Vol. 49, No. 4, pp. 1057-1072.

Eichenbaum, Martin, and Charles Evans, 1995, "Some Empirical Evidence on the Effects of Monetary Policy Shocks on Real Exchange Rates," Quarterly Journal of Economics, Vol. 110, No. 4, pp. 975-1009.

Engle, Robert F., 1982, "A General Approach to Lagrange Multiplier Model Diagnostics," Journal of Econometrics, Vol. 20, No. 1, pp. 83-104.

— Estimation, and Testing," Econometrica, Vol. 55, No. 2, pp. 251-276.

Faruqee, Hamid, and Guy Debelle, 2000, "Saving-Investment Balances in Industrial Countries: An Empirical Investigation," in Exchange Rate Assessment: Extensions of the Macroeconomic Balance Approach, ed. by Peter Isard and Hamid Faruqee, Occasional Paper 167 (Washington: International Monetary Fund), Ch. VI, pp. 35-55.

Fayan, Gabriel, Jerome Henry, and Ricardo Mestre, 2001, "An Area Wide Model (AWM) for the Euro Area, ECB Working Paper No. 42 (Frankfurt: European Central Bank).

Freund, Caroline L., 2000, "Current Account Adjustment in Industrialized Countries," International Finance Discussion Paper No. 692 (Washington: Board of Governors of the Federal Reserve System).

Gali, Jordi, 1999, "Technology, Employment and the Business Cycle: Do Technology Shocks Explain Aggregate Fluctuations?" American Economic Review, Vol. 89, No. 1, pp. 249-71.

Hoffmann, Mathias, 2003, "International Macroeconomic Fluctuations and the Current Account," Canadian Journal of Economics, Vol. 36, No. 2, pp.401-420.

Houthakker, Hendrik S., and Stephen P. Magee, 1969, "Income and Price Elasticities in World Trade," Review of Economics and Statistics, Vol. 51, No. 2, pp. 1041-1105.

International Monetary Fund, 1993, “Balance of Payments Manual,” Fifth Edition, reprinted 1997, Washington. 
Johansen, Soren, 1988, "Statistical Analysis of Cointegration Vectors," Journal of Economic Dynamics and Control, Vol. 12, No. 2/3, pp. 231-254.

— 1992 , "Cointegration in Partial Systems and the Efficiency of Single-Equation Analysis," Journal of Econometrics, Vol. 52, No. 2, pp. 389-402.

Kandil, Magda, and Joshua Greene, 2002, "The Impact of Cyclical Factors on the United States Balance of Payments," IMF Working Paper No. 02/45 (Washington: International Monetary Fund).

Kraay, Aart, and Jaume Ventura, 2002, "Current Accounts in the Long and Short Run," NBER Working Paper No. 9030 (Cambridge, Mass.: National Bureau for Economic Research).

Krugman, Paul, 1989, "Differences in Income Elasticities and Trends in Relative Exchange Rates," European Economic Review, Vol. 33, No. 5, pp. 1031-54.

Lane, Philip, 1999, "Money Shocks and the Current Account," (Unpublished Manuscript: Dublin, Trinity College).

Leonard, Greg and Alan C. Stockman, 2001, "Current Accounts and Exchange Rates: A New Look at the Evidence," NBER Working Paper No. 8361 (Cambridge, Mass.: National Bureau for Economic Research).

McKinnon, Ronald, 2001, "The International Dollar Standard and the Sustainability of the UNITED STATES Current Account Deficit," Brookings Papers on Economic Activity, No. 1, pp. 227-39.

Milesi-Ferretti, Gian Maria and Assaf Razin, 1996, "Current Account Sustainability," Princeton Studies in International Finance No. 81 (Princeton, N. J. :International Finance Section, Princeton University).

Muller-Plantenberg, Nikolas, 2003, "Current Account Reversals Triggered by Large Exchange Rate Movements," (Unpublished Manuscript, London: London School of Economics).

Obstfeld, Maurice and Kenneth Rogoff, 1995, "Exchange Rate Dynamics Redux," Journal of Political Economy, Vol. 103, No. 3, pp. 620-60.

Pagan, Adrian, 1984, "Econometric Issues in the Analysis of Regressions with Generated Regressors," International Economic Review, Vol. 25, No. 1, pp. 221-47.

— 1986, "Two Stage and Related Estimators and Their Applications, Review of Economic Studies, Vol. 53, No. 4, pp. 517-38.

Patterson, Kerry, 2000, An Introduction to Applied Econometrics- A Time Series Approach, (London: Macmillan). 
Prasad, Eswar. S., 1999, "International Trade and the Business Cycle," Economic Journal, Vol. 109, No. 458, pp. 588-606.

Romer, Christina D. and Romer, David H., 1989, "Does Monetary Policy Matter?" in NBER Macroeconomics Annual, ed. by Olivier Blanchard and Stanley Fischer (Cambridge Mass.: MIT Press), pp. 121-170.

Sarisoy-Guerin, Selen, 2003, "The Relationship between Capital Flows and Current Account: Volatility and Causality," (Unpublished Manuscript, Dublin: Trinity College).

Stock, James H. and Mark W. Watson, 2003, "Understanding Changes in International Business Cycle Dynamics," NBER Working Paper No. 9859 (Cambridge, Mass.: National Bureau for Economic Research). 